\title{
Review Article \\ Carotenoids Functionality, Sources, and Processing by Supercritical Technology: A Review
}

\author{
Natália Mezzomo and Sandra R. S. Ferreira \\ EQA-CTC/UFSC, Chemical and Food Engineering Department, Federal University of Santa Catarina, \\ CP 476, 88040-900 Florianópolis, SC, Brazil
}

Correspondence should be addressed to Natália Mezzomo; natimezzomo@gmail.com

Received 30 November 2015; Revised 25 January 2016; Accepted 3 February 2016

Academic Editor: Artur M. S. Silva

Copyright (C) 2016 N. Mezzomo and S. R. S. Ferreira. This is an open access article distributed under the Creative Commons Attribution License, which permits unrestricted use, distribution, and reproduction in any medium, provided the original work is properly cited.

\begin{abstract}
Carotenoid is a group of pigments naturally present in vegetal raw materials that have biological properties. These pigments have been used mainly in food, pharmaceutical, and cosmetic industries. Currently, the industrial production is executed through chemical synthesis, but natural alternatives of carotenoid production/attainment are in development. The carotenoid extraction occurs generally with vegetal oil and organic solvents, but supercritical technology is an alternative technique to the recovery of these compounds, presenting many advantages when compared to conventional process. Brazil has an ample diversity of vegetal sources inadequately investigated and, then, a major development of optimization and validation of carotenoid production/attainment methods is necessary, so that the benefits of these pigments can be delivered to the consumer.
\end{abstract}

\section{Introduction}

Carotenoids are a class of compounds that have coloring power and have been widely used in food industry, leading its market to full development. Carotenoids occur widely in nature and, in general, all fruits and vegetables of color are good sources of these compounds. Currently, the carotenoids used industrially are synthesized chemically, but a small portion is obtained through extraction from plants or algae. Considering the fact that there is a high demand and consumer preference for natural compounds, there is a global trend in increasing the use of products made with natural ingredients.

Natural alternatives of production/attainment are being studied. The main subjects of these works are the investigation of vegetal sources containing high carotenoids concentrations and producer microorganisms and their optimum conditions for bioproduction. Many organisms produce carotenoids, but not all are industrially interesting. Yeast is distinguished for its use as a protein source and growing ability on low cost substrates with high sugar content, but the amount and type of carotenoids produced by their microorganisms can vary according to the operational conditions of growth.
In order to be able to separate these compounds, feasible extraction methods to obtain them from natural sources or microorganisms are being intensively investigated in order to determine the optimum conditions to have better performance and stability. The extraction of pigments from plant tissues and microbial biomass, especially made of fat-soluble pigments (such as carotenoids), usually uses vegetal oils and organic solvents. In contrast, the negative impact of most organic solvents on the environment and human health is known. Thus, supercritical technology emerges as an alternative technique for the carotenoids recovery from microorganisms' producers or directly from vegetal sources, and its study is in widespread development.

In this context, the objective of this study was to investigate the occurrence, extraction, and production of pigments from natural or bioproduced sources, doing a literature review of the technological and nutritional status of the currently known major carotenoids.

\section{Carotenoids Definition and Structure}

"Carotenoids" is a generic term used to designate the majority of pigments naturally found in animal and plant kingdoms. 


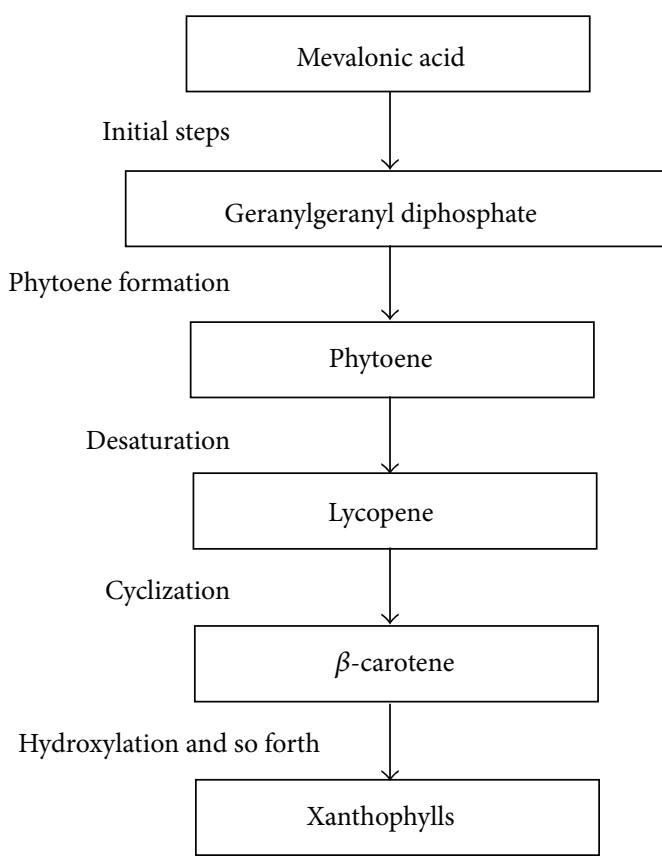

FIGURE 1: Flowchart summary of the carotenoids biosynthesis stages. Reference: Britton et al. [4].

This group of fat-soluble pigments comprises more than 700 compounds responsible for the red, orange, and yellow colors. Most carotenoids are hydrocarbons containing 40 carbon atoms and two terminal rings [1].

All photosynthetic organisms (including plants algae and cyanobacteria) and some nonphotosynthetic bacteria and fungi synthesize the carotenoids. Two classes of carotenoids are found in nature: (a) the carotenes such as $\beta$-carotene, which consist of linear hydrocarbons that can be cyclized at one end or both ends of the molecule, and (b) the oxygenated derivatives of carotenes such as lutein, violaxanthin, neoxanthin, and zeaxanthin, known as xanthophylls [2].

Most carotenoids are tetraterpenoids (C40) consisting of 8 units isoprenoids linked so that the molecule is linear and symmetrical, with the order reversed in the center. The basic cyclic structure can be modified by hydrogenation, dehydrogenation, cyclization, and oxidation, as shown in Figure 1. The system of conjugated double bonds gives these pigments high chemical reactivity that can be easily isomerized and oxidized [3]. Figure 2 shows the structure of some carotenoids.

\section{Carotenoids Properties and Functions}

Due to the coloring properties of carotenoids, they are often used in food, pharmaceutical, cosmetics, and animal feed industries. In addition to their extensive use as colorants, they are also used in food fortification because of their possible activity as provitamin $\mathrm{A}$ and their biological functions to health benefit, such as strengthening the immune system, reducing the risk of degenerative diseases [5], antioxidant properties [1,6] and antiobesity/hypolipidemic activities [6].
From several hundred naturally occurring carotenoids, only 50 have significant biological activity and they can be divided into two groups, with and without the provitamin A. The carotenoids that are precursors of vitamin A should have at least one ring of $\beta$-ionone not replaced and side polienic chain with at least 11 carbons [7].

Vitamin A is important for growth, development, maintenance of epithelial tissues, reproduction, immune system, and, in particular, visual cycle acting in the regeneration of photoreceptors [7]. Its deficiency is a serious problem of public health, being the major cause of infant mortality in developing countries. A prolonged deficiency can produce changes in the skin, night blindness, and corneal ulcers. Besides, it leads to blindness, growth disorders, and learning difficulties in childhood [8]. On the other hand, vitamin A in excess is toxic and can cause congenital malformation during pregnancy, bone disease in patients with chronic renal failure, xerophthalmia, blindness, and death $[7,8]$.

Carotenoids are converted to vitamin $\mathrm{A}$ as the body needs, with varying degrees of conversion efficiency. The forms of provitamin A carotene are found in dark green and yellow-orange leafy. Darker colors are associated with higher levels of this provitamin [8].

Carotenoids, along with vitamins, are the substances most investigated as chemopreventive agents, acting as antioxidants in biological systems [9]. Antioxidants can act directly in the neutralization of free radicals, preventing or reducing damage caused by these compounds in cells, or indirectly involved in enzyme systems that have antioxidant activity [10].

From the nonenzymatic compounds, on antioxidant defense, some minerals (copper, manganese, zinc, selenium, and iron), vitamins (ascorbic acid, vitamin $\mathrm{E}$, and vitamin A), carotenoids ( $\beta$-carotene, lycopene, and lutein), bioflavonoids (genistein, quercetin), and tannins (catechins) can be detached [11].

Studies show the relationship between increased consumption of foods rich in carotenoids and the risk reduction of various diseases. According to Olson [12], carotenoids quench singlet oxygen, remove peroxy radicals, modulate carcinogen metabolism, inhibit cell proliferation, stimulate communication between cells (gap junctions), and increase the immune response. Tests in vitro and in vivo suggest that carotenoids are excellent antioxidants, scavenging and inactivating free radicals [13].

Both carotenoids that are precursors of vitamin $\mathrm{A}$ and the nonprecursors, such as lutein, zeaxanthin, and lycopene, have protective action against cancer [33]. Still, from the important biological activities of these compounds, the inhibition of other diseases is detached where free radicals play role as atherosclerosis, cataracts, macular degeneration, multiple sclerosis, degenerative diseases, and cardiovascular diseases [34-36].

Due to the high unsaturation rate, factors such as heat, light, and acids cause trans-isomerization of carotenoids, which is the most stable form in nature, for the cis-form, promoting a slight loss of color and provitamin activity. Carotenoids are also susceptible to enzymatic or nonenzymatic oxidation, which depends on the carotenoid structure, 
<smiles>CC1=C[C@H](O)CC(C)(C)C1/C=C/C(C)=C/C=C/C(C)=C/C=C/C=C(C)/C=C/C=C(C)/C=C/C1=C(C)C[C@H](C)CC1(C)C</smiles>

(B)<smiles>CC1=C(/C=C/C(C)=C/C=C/C(C)=C/C=C/C=C(C)/C=C/C=C(C)/C=C/C2=C(C)CC(C)CC2(C)C)C(C)(C)CCC1</smiles>

(C)<smiles>CC1=C(/C=C/C(C)=C/C=C/C(C)=C/C=C/C=C(C)/C=C/C=C(C)/C=C/C2=C(C)[C@H](O)CC2(C)C)C(C)(C)C[C@H](O)C1=O</smiles>

(a)<smiles>CC(C)=CCC/C(C)=C/C=C/C(C)=C/C=C/C(C)=C/C=C/C=C(C)/C=C/C=C(\C)CC/C=C(\C)CCC=C(C)C</smiles>

(E)<smiles>CC(C)=CCC/C(C)=C/C=C/C(C)=C/C=C/C(C)=C/C=C/C=C(C)/C=C/C=C(C)/C=C/C=C(\C)CCC=C(C)C</smiles>

(F)<smiles>CC1=C(/C=C/C(C)=C/C=C/C(C)=C/C=C/C=C(C)/C=C/C=C(C)/C=C/C2=C(C)CCCC2(C)C)C(C)(C)CCC1</smiles>

(G)<smiles>CC1=CCCC(C)(C)C1/C=C/C(C)=C/C=C/C(C)=C/C=C/C=C(C)/C=C/C=C(C)/C=C/C1=C(C)CCCC1(C)C</smiles>

(H)

(b)

FIGURE 2: Carotenoids structure: (a) xanthophylls: (A) zeaxanthin, (B) lutein, (C) beta-cryptoxanthin, and (D) astaxanthin; (b) Carotenes: (E) neurosporene, (F) lycopene, (G) $\beta$-carotene, and (H) $\alpha$-carotene. Reference: Britton et al. [4]. 
the oxygen availability, enzymes, metals, prooxidants and antioxidants, high temperature, and light exposure [37].

Carotenoids are hydrophobic compounds, lipophilic, insoluble in water, and soluble in solvents such as acetone, alcohol, and chloroform [38]. Because carotenoids are fatsoluble pigments widely distributed in nature, they have broad utility because of their coloring power [5].

In food industries, the carotenoids are mainly used as restoring colorants, used in products submitted to intense processing/storage (which lost part of their natural color), or in order to standardize the food products color, such as in fruit juices, pasta, beverages, candies, margarines, cheeses, and sausages. They are also precursors of many important chemical compounds responsible for the flavor of some foods, such as alkaloids and volatile compounds, and fragrances of some flowers and staining of photoprotection [39]. Indirectly, through their application in feed, these pigments serve to intensify the color of egg yolk, chicken skin, fish, and milk [40]. Astaxanthin, the main carotenoid found in crustaceans, is an effective agent pigment when incorporated in salmonids and crustaceans diets [41-43].

More recently, with the growing interest in maintaining health through natural products, carotenoids have also been added to foods due to their biological activities listed above, in order to enrich the food product. Furthermore, in the cosmetic and pharmaceutical industries, they can be used only for the purpose of coloring medicine capsules, supplements, and cosmetics [40].

In commercial formulations, the carotenoids used may be of two types: natural extracts or synthetic colors identical to natural ones. The great demand generated by industries and the growing demand for natural products have resulted in an increase in research concerning the bioproduction and extraction of carotenoids. In addition to the connotation "natural," the products are simply obtained by extraction from natural sources or through microbial production followed by extraction, which can be achieved in a short period at any time of year [44].

The pigments can absorb light in particular ultraviolet (UV) and visible spectrum, showing color. The structure responsible for light absorption is the chromophore group, which in carotenoids is characterized by conjugated double bonds. Each carotenoid is characterized by an electronic absorption spectrum. Thus, absorption spectroscopy is an important technique in the analysis of carotenoids [45].

3.1. $\beta$-Carotene. The $\beta$-carotene is a thermolabile orange pigment, light, and oxygen sensitive, and it is associated with protection against heart disease and cancer $[46,47]$, due to its potential protection mechanisms already cited. Still, the oxidation of LDL-cholesterol is a crucial factor for the atherosclerosis development and $\beta$-carotene acts by inhibiting the lipoprotein oxidation [38].

A study conducted at the State University of New York showed that the consumption of vegetables rich in $\beta$-carotene more than once a week significantly reduces the lung cancer risk in relation to individuals who did not consume these vegetables [48].
3.2. Lycopene. The pigment lycopene belongs to the subgroup of nonoxygenated carotenoids, being characterized by a symmetric structure containing 11 conjugated double bonds [49]. Due to its chemical structure, lycopene stands as one of the best biological suppressors of free radicals [49-51]. Among a series of measured carotenoids, lycopene was shown to be one of the most effective antioxidants and may donate electrons to neutralize the singlet oxygen molecules and other oxidizing molecules before they affect the cells $[50,51]$, with twice the antioxidant activity when compared to $\beta$-carotene $[52,53]$.

Clinical and epidemiological studies have confirmed that diets rich in lycopene are associated with reduced risk of developing prostate lung and ovary cancers and a lower incidence of chronic degenerative diseases and cardiovascular diseases $[49,54,55]$. It is interesting to note that some more recent studies indicated that lycopene intake present in tomato fruit is more effective in preventing certain types of cancer than the administration of purified lycopene by capsules [56].

3.3. Lutein and Zeaxanthin. Lutein and zeaxanthin are carotenoids stored in our body in the retina and lens eyes [38]. Some studies have shown that high lutein and zeaxanthin intake, particularly from foods rich in xanthophylls such as spinach, broccoli, and eggs, are related to the significant reduction of cataract (over 20\%) and macular degeneration related to age (over 40\%) [57].

3.4. Astaxanthin. Astaxanthin is a pigment found in aquatic animals, such as lobster, crab, and shrimp. A growing interest in the use of astaxanthin for poultry and fish-farming has been developed [41-43, 58], once this pigment is not synthesized by animals and must be added to the diets in order to obtain a color attractive to consumers.

This xanthophyll has antioxidant power 10 times greater than $\beta$-carotene and 500 times higher than vitamin $\mathrm{E}$ [26]. In addition, this pigment has been important in some diseases treatment and prevention, with antitumor properties and protection against free radicals, lipid peroxidation, oxidative damage to LDL-cholesterol, oxidation of essential polyunsaturated fatty acids, and the UV light effects on cell membranes and tissues [59].

The incorporation of astaxanthin in feed for aquaculture is effective for salmonids and crustaceans pigmentation, so its presence in shrimp, lobster, crab, and other shellfish exoskeletons has been investigated [42, 60-62]. Wathne et al. [43] and Pangantihon-Kühlmann et al. [58] observed increase of color intensity in salmon and shrimp, respectively, using diets containing astaxanthin in the diet.

\section{Carotenoids Occurrence and Natural Production}

Carotenoids are natural pigments that occur widely in nature. Plants and some microorganisms produce these pigments; however, animals must obtain them through diet [63]. The carotenoids market is in full progress and most of these pigments used industrially are synthesized chemically, for example, astaxanthin, canthaxanthin, and $\beta$-carotene [64]. Thus, 
natural alternatives are being studied because of growing concerns about food safety and the negative aspects of the coloring production, such as carotenoids, by chemical synthesis [65].

4.1. Natural Sources. All color fruits and vegetables are good carotenoids sources, but because they are fat-soluble substances, the absorption largely depends on their preparation with oils or fats. The forms of carotene provitamin A are found in dark green and yellow-orange leafy. Darker colors are associated with higher levels of provitamin [7].

Among the carotenoids, the $\beta$-carotene is the most abundant in foods that has the highest activity provitamin A. It can be found in large quantities in buriti (Mauritia vinifera Mart.) [66], tucumã (Acrocomia mokayáyba Barb. Rodr.), bocaiúva [67], acerola, mango [68], some varieties of pumpkin [69], carrot [70], nuts [71], camu-camu (Myrciaria dubia) [72], carrot noodles [73], rose hip fruits [74], and oil palm [75], which is an excellent source due to being free from any barrier of vegetal matrix and thus has increased bioavailability of this pigment "beta-carotene" [38].

Lycopene is a red pigment that occurs naturally only in vegetables and algae tissues. Currently, the most cited sources of lycopene are the tomato and its derivatives, such as juices, soups, sauces, and ketchup [76], including the processing waste $[77,78]$ and peel [79]. However, it can be found in even higher concentrations in cherry, guava, and guava products [80], at similar concentrations in watermelon [81] and Thai papaya, and in lower quantities in Solo and Formosa cultivars of papaya [82].

Both lutein and zeaxanthin are present in green and dark green leafy vegetables, like broccoli, Brussels sprouts, spinach, and parsley [38]. Some varieties of pumpkin [69], acerola [83], and leafy vegetables in general [84] are also good lutein and $\beta$-carotene sources. The Tropaeolum majus L.53 edible flower is also a rich lutein source and it still appears in good quantity in caja (Spondias lutea) [85] and camu-camu (Myrciaria dubia) [72]. Some microalgae also produce lutein, such as Chlorella vulgaris [86], Chlorella sorokiniana MB-1 [87], and the indigenous microalga Scenedesmus obliquus CNW$\mathrm{N}$ [88]. Zeaxanthin is found in high concentrations in pequi (Caryocar villosum) [5] and also the native marine microalgae Chlorella saccharophila [89].

Astaxanthin is a reddish-pink pigment found in aquatic animals, such as lobster, crab, and shrimp [65], including their processing waste $[90,91]$. In addition, the microalgae Phaffia rhodozyma, Chlorella vulgaris, and Haematococcus pluvialis synthetize large amount of astaxanthin $[92,93]$.

4.2. Bioproduction. According to Silva [94], the biotechnological production of carotenoids has been increasing due to factors such as the using possibility of low cost substrates; designation of natural substances; small area required to bioproduction; being not subject to environmental conditions such as climate, season, or soil composition; and control of culture conditions.

Carotenoids may be biosynthesized by photosynthetic organisms, as, for example, algae and cyanobacteria (blue and green), and nonphotosynthetic microorganisms such as bacteria, fungi, and yeasts [37].

The carotenoids production by biotechnological process has been widely investigated, dethatching the commercial production of $\beta$-carotene by the fungus Blakeslea trispora [95], the marine microalgae Dunaliella [96], the astaxanthin production by the freshwater microalga Haematococcus sp., and the yeast Phaffia rhodozyma [37].

The Dunaliella microalgae are rich in $\beta$-carotene and other large application carotenoids. India has the largest manufacturing industry of these microalgae, where the $\beta$ carotene is intended for pharmaceutical use. Other major producers are located in Australia, United States, China, Mongolia, and Japan; small plants are also found in Mexico, Chile, Cuba, Iran, and Taiwan [97].

The industrial production of astaxanthin by Haematococcus also presents great interest due to its high commercial value of this pigment and the high market growth of aquaculture. The world's major producers are located in the United States, Japan, and India [97].

The production of natural pigments in industrial scale and the high value of the products make the biotechnological process of carotenoids an area of intense study. The bioprocess productivity in a given system depends on the nutritional and physical conditions of the microorganism, affecting not only cell growth as the pigment production. Therefore, microorganisms accumulate different carotenoids in response to the stress of environmental conditions [35].

Improving the efficiency of carotenoids biosynthesis can increase production. In addition to growing conditions, the carotenoids biosynthesis is controlled by the biosynthetic enzymes level and activity, beyond the total carbon flow of the synthesizing system [35].

According to Bhosale [35], we can achieve a better carotenoids production with low cost using stimulants in the culture medium and adjusting the external conditions of cultivation. Silva [94] studied the effects of various chemicals (acid, $\beta$-ionone, mevalonic acid, diphenylamine, and other amino acids) in the carotenoids biosynthesis by Rhodotorula yeasts in order to increase and direct the carotenogenesis. Acetic acid had no effect on growth and production of pigment, but the $\beta$-ionone inhibited the growth and carotenogenesis. The mevalonic acid stimulated the carotenoids formation in $120 \%$ for R. mucilaginosa and 35\% for R. glutinis, without affecting the cells production of these microorganisms.

The cultivation ability of yeast in media with high sugar content makes these microorganisms industrially interesting. Yeasts such as Xanthophyllomyces dendrorhous [98], Rhodotorula glutinis [36], Rhodotorula mucilaginosa [36], Sporobolomyces [99], and Phaffia [100] are being studied in order to maximize the carotenoids bioproduction, aiming at the industrial use.

Microorganisms that are technologically interesting and with high potential to be used in carotenoids bioproduction are the cyanobacteria Anabaena variabilis, Aphanizomenon flos-aquae, and Nostoc commune in the production of canthaxanthin [37]; algae Chlorella pyrenoidosa, Dictycoccus cinnabarinus, Dunaliella salina, Dunaliella tertiolecta, 
Haematococcus pluvialis, and Spongiococcum excetricum in the production of lutein, canthaxanthin [37], $\beta$-carotene [101], $\beta$-carotene [102], astaxanthin [103], and lutein [37], respectively; fungi and Blakeslea trispora yeasts in the production of $\beta$-carotene and lycopene [37]; Dacrymyces deliquescens in the production of lutein [37]; Phaffia rhodozyma in the production of astaxanthin and $\beta$-carotene [100]; Rhodosporidium sp., Rhodotorula glutinis, and Rhodotorula graminis to produce torulene and $\beta$-carotene [37]; Sporidiobolus salmonicolor in production of $\beta$-carotene [104]; and the Mycobacterium brevicaie, Mycobacterium lacticola, Streptomyces chrestomyceticus, and Rhodococcus maris bacteria in the production of canthaxanthin, astaxanthin, canthaxanthin, and xanthophylls [37], respectively.

\section{Carotenoids Extraction and Recovery}

The industrial bioproduction of carotenoids is well established and has been expanding commercially. However, the operations of product extraction and recovery and direct extraction from marine or vegetal sources are still under development in the literature. Moreover, the extraction processes contribute to increasing production costs, emphasizing the need for detailed research in this area.

The main techniques of extraction used in studies of carotenoids recovery are the conventional technique using organic solvents or vegetal oils and supercritical fluid extraction. Each of these techniques is based on different fundamentals, according to the main mechanism responsible for the extraction, as it will be explained below.

5.1. Raw Material Pretreatment before Extraction. Kaiser et al. [105] evaluated a method on a small scale combining hydrolysis technique, in order to facilitate the carotenoids extraction bioproduced by Micrococcus luteus and Rhodotorula glutinis, with minimum degradation. The methodology was evaluated by combining two enzymes (lysozyme and lipase or lyticase and lipase), followed by mechanical treatment with freezing and ultrasonic cycles followed by chemical treatment with dimethylsulfoxide. For the extraction, they used a methanol/chloroform mixture, stabilized with butylated hydroxytoluene (BTH) and $\alpha$-tocopherol. For the recovery and reproducibility evaluation of the extraction method, carotenoids internal standard was used. The extraction method proved to be a sensitive tool in the carotenoids determination derived from microorganisms.

Perdigão et al. [106] studied the pigments extraction from lobster, shrimp, and crab shells. The raw materials were or were not subjected to cooking by immersion in boiling water, drying in an oven with air circulation at $60^{\circ} \mathrm{C}$ during 5 hours, and crushing to a particle size of $2 \mathrm{~mm}$. Then, the samples were added to refined soybean oil on a $1: 1(\mathrm{w} / \mathrm{v})$ ratio and heated at $80^{\circ} \mathrm{C}$ in a water bath during $30 \mathrm{~min}$. The carotenoid enriched oil was separated from the matrix by centrifugation and the carotenoids levels were measured. Pretreated samples using cooking presented the highest pigment content, which means that this pretreatment can cause a break on the carotenoid-protein complex, facilitating extraction. The red lobster (Panulirus argus) showed the highest concentration of astaxanthin $(7.73 \mathrm{mg} / 100 \mathrm{~g})$ when compared to the green lobster (Panulirus laevicauda) (5.50 mg/100 g); the pink (Penaeus (Farfantepenaeus) subtilis) and white (P. (Litopenaeus) schmitti) shrimp showed carotenoids content of 12.66 and $9.93 \mathrm{mg}$ astaxanthin/100 g of pigmented oil, respectively; and the aratu crab (Goniopsis cruentata) showed a considerable astaxanthin content $(17.7 \mathrm{mg} / 100 \mathrm{~g})$, followed by the uçá crab (Ucides cordatus cordatus) $(3.15 \mathrm{mg} / 100 \mathrm{~g})$ and guaiamum crab (Cardisoma guanhumi) (2.11 mg/100 g).

Mezzomo et al. [90] evaluated the use of isolated or combined pretreatments in order to break the carotenoidprotein complex from pink shrimp ( $P$. brasiliensis and $P$. paulensis) processing residue, simplifying the carotenoid extraction. The pretreatment processes evaluated were quick cooking during $10 \mathrm{~min}$, drying at $60^{\circ} \mathrm{C}$ during $5 \mathrm{~h}$, and milling in domestic blender. The results indicated that the best raw material pretreatment, in terms of extraction yield and total carotenoid content, is the combination of the three procedures tested.

Gu et al. [107] compared three previous treatments to the extraction (ultrasound, grinding, and addition of $\mathrm{HCl}$ ), and in order to optimize the extraction process, they evaluated the temperature $\left(10\right.$ to $\left.70^{\circ} \mathrm{C}\right)$, solute/solvent ratio (10 to $130 \mathrm{v} / \mathrm{m}$ ), and time (10 to $130 \mathrm{~min}$ ) effects on extraction yield of carotenoids from $R$. sphaeroides. The results proved that the pretreatment using $\mathrm{HCl}$ was the most effective method for the carotenoids extraction. In the optimization stage, the best results of carotenoids extraction from $R$. sphaeroides were found when they used $30^{\circ} \mathrm{C}$ of temperature and optimum solute/solvent ratio of 40 , and maximum carotenoids extraction was obtained at the time of $40 \mathrm{~min}$.

Guillou et al. [42] affirmed that, according to the literature, total extraction of the carotenoids from crab shell can be only achieved using acetone or methanol, after shell decalcification with acetic acid. Omara-Alwala et al. [41] reported that the use of propionic acid increased by $35 \%$ in the astaxanthin recovery from lobsters waste. Guillou et al. [42] obtained a $15 \%$ higher extraction of astaxanthin in shrimp (Pandalus borealis) waste subjected to silage when compared with the "in natura" (crude) extraction residue.

Enzymatic hydrolysis has been considered a viable method as pretreatment for the astaxanthin recovery [108, 109]. Holanda [110] performed organic solvent extraction of carotenoids from shrimp waste and obtained an extraction two times more efficient than using oil, in both untreated waste and soluble and insoluble fractions obtained after enzymatic hydrolysis. In the solvent extraction, the recovery was 17 to $31 \%$ higher after enzymatic hydrolysis. The best recovery was $12.01 \mathrm{mg}$ astaxanthin/100 g dry residue, when hydrolysis is done with alcalase. Most of astaxanthin (approximately $70 \%$ ) was from the insoluble fraction and the authors found that the orange color of the pigment still stood in the matrix, indicating that both the oil and the solvents used were not able to extract the total astaxanthin present in the insoluble fraction.

Chen and Meyers [61] observed a slight increase (from 3 to $5 \%$ ) in the astaxanthin extraction with an increase of the hydrolysis time for shrimp (Solenocera melantho) waste with several commercial proteases. Still, extraction differences 
were observed when distinct proteolytic enzymes were used. According to the authors, the increase in extraction, observed with increasing time of hydrolysis and the enzyme used, is probably due to a break in carotenoid-protein link that would allow the recovery of oil or solvent.

Due to the strong association of carotenoids with the cells of the producers' microorganisms and in order to maximize the extraction of the pigments, Valduga et al. [104] tested 11 different methods of cell disruption and solvent extraction. It was found that when using a liquid nitrogen and dimethylsulfoxide combination for cell disruption and extraction with acetone and methanol $(7: 3, \mathrm{v} / \mathrm{v})$ mixture, they obtained the highest carotenoids recovery from the $S$. salmonicolor yeast grown on agar YM (Yeast Malt Extract Agar).

Rawson et al. [111] studied the effect of ultrasound and blanching pretreatments on carotenoid compounds of hot air- and freeze-dried carrot discs. Ultrasound pretreatment followed by hot-air-drying at the highest amplitude and treatment time investigated resulted in higher retention of carotenoids in dried carrot discs than blanching followed by hot-air-drying. In addition, the freeze-dried samples had a higher retention of carotenoid compounds compared to hot air dried samples. This study showed that ultrasound pretreatment is a potential alternative to conventional blanching treatment in the carrots drying.

The effect of enzymatic pretreatment, using pectinase on the carotenoids content from Gac fruit (Momordica cochinchinensis Spreng) aril, was evaluated by Kha et al. [21]. The results indicated the highest oil extraction and enhancement of the carotenoids content, specially the $\beta$-carotene concentration, when using the enzyme concentration at $0.1 \%(\mathrm{w} / \mathrm{w})$ for pretreatment before air-drying.

Strati et al. [78] also studied the use of pectinase and cellulase enzymes to assist the high-pressure extraction of carotenoids from tomato waste. As a result, authors proved that the total carotenoid and lycopene extraction yields were increased by the use of the enzymes before the extraction, when compared to the nonenzyme process.

5.2. Conventional Technique of Extraction. The extraction and recovery of carotenoids, either from bioproduction or directly from plant and animal sources, can conduce using vegetable oils or organic solvents.

The extraction with organic solvents is based on using high operating temperatures and demonstrates solventcomponents interactions, which is a function of chemical affinity between the species in the system [112]. Carotenoids are compounds of low polarity and therefore soluble in solvents of low polarity such as hexane. However, these organic molecules have also a polar part, soluble in polar solvents, increasing the range of organic solvents useful in the carotenoids extraction.

When an organic solvent is used in its boiling temperature, the solvent surface tension and viscosity are very small when compared to a lower temperature. Thus, the solvent can reach easily the solute on certain matrix spaces, solubilizing a greater amount and variety of solutes [112].
The solvent recovery is a crucial period in the extraction process with organic solvents, mainly due to environmental and economic problems. Thus, extraction with organic solvents has other major disadvantages, that is, the possible thermal degradation of the extract and the incomplete solvent removal; it is a lazy process and has low selectivity [113].

Nevertheless, the extraction with organic solvents is effective in the extraction of carotenoids [114, 115]. However, as previously reported, the high temperatures required for the removal of the solvents can result in degradation of pigment, and the final product may contain trace amounts of solvent and, consequently, reduce their potential for use in food products [116].

Vegetable oils have been used as a solvent for extraction of carotenoids. The advantage of using vegetable oils is that they are considered a good barrier against oxygen, slowing oxidation processes, in addition to being used as energy source in the subsequent application in foods $[61,62,117,118]$. The solvent removing step is not used when using vegetable oil, and the resultant product consists in a mixture of oil/extract rich in carotenoids, and the process may not present the drawbacks of extracts thermal degradation.

Gildberg and Stenberg [109] used extraction with organic solvent ( $\mathrm{HCl}$ and water) of shrimp (Pandalus borealis) waste and found concentration of $150.0 \mathrm{mg}$ astaxanthin/100 $\mathrm{g}$ of residue, and this value was 10 times higher than the values found in literature for oil extraction. Chen and Meyers [61] found $16.15 \mathrm{mg}$ astaxanthin/100 g of crayfish waste, using solvent, against $8.0 \mathrm{mg}$ astaxanthin/100 g with oil extraction. Meyers and Bligh [62] achieved concentration of $15.3 \mathrm{mg}$ astaxanthin/100 $\mathrm{g}$ of residue in crayfish waste with extraction using organic solvent. These differences are due to distinct available quantities of carotenoids in feed, environmental conditions and species [109], and the method used for extraction and quantification of astaxanthin. Variables such as the particle size of the waste, temperature, and residue/solvent ratio can also lead to differences in extraction.

Shahidi and Synowiecki [117] and Saito and Regier [119] used shrimp (Pandalus borealis) waste and crab (Chionoecetes opilio) shell for astaxanthin and chitin extraction. In the extraction of carotenoids, they used cod liver oil ( 2 amounts of oil : 1 part of residue, $\mathrm{v} / \mathrm{m}$ ) at $60^{\circ} \mathrm{C}$ during $30 \mathrm{~min}$. Then, the mixture was filtered and dried under vacuum at $60^{\circ} \mathrm{C}$, separating the water from the carotenoids extract. The results indicated $74 \%$ of astaxanthin extraction from shrimp waste ( $14.77 \mathrm{mg} / 100 \mathrm{~g}$ dry residue) and $56 \%$ of the crab shell (11.9 mg/100 g dry weight).

Sachindra and Mahendrakar [120] determined the extraction yield of carotenoids from shrimp waste, extracted using different vegetable oils (sunflower oil, groundnut oil, gingerly oil, mustard oil, soy oil, coconut oil, and rice bran oil). The method applied consists in the homogenization and mixing of shrimp waste with the selected oil, followed by heating, filtration, centrifugation, and separation of pigmented oil. The results of the carotenoid yield (spectrophotometrically determined) indicated superiority of the sunflower oil and were significantly influenced by level of oil to waste, time, and temperature of heating before centrifugation to separate pigmented oil. The best conditions for extraction of shrimp waste 
carotenoids in sunflower oil were determined to be oil level to waste of 2 , temperature of $70^{\circ} \mathrm{C}$, and heating time of $150 \mathrm{~min}$.

Taungbodhitham et al. [121] evaluated a carotenoids extracting method in order to be used by a wide variety of vegetal sources. As representative sample was used tomato juice and to the extraction method were selected 2 low environmental impact solvents (ethanol and hexane). They used mixtures of these solvents, with a $4: 3(\mathrm{v} / \mathrm{v})$ ratio, respectively, of ethanol and hexane, resulting in good conversions of carotenoids in juice ( $96 \%$ of lycopene, $102 \% \alpha$-carotene, and 93\% of $\beta$-carotene). In order to evaluate the method applicability to other kinds of fruits and vegetables, the authors used carrots, spinach, and tomato juice added to carotenoids. The added carotenoids recovery was, respectively, for tomato juice, carrot, and spinach as follows: $100 \%, 101 \%$, and $99.8 \%$ for $\alpha$-carotene and $98.1 \%, 99.7 \%$, and $96.1 \%$ for the $\beta$ carotene. These results indicated that the extraction method for different vegetal matrixes was established.

5.3. Supercritical Fluid Extraction (SFE). The supercritical technology using carbon dioxide $\left(\mathrm{CO}_{2}\right)$ near the critical point as a solvent in the extraction of compounds such as carotenoids has been considered as an alternative to employment in food and pharmaceutical industries [122]. The use of supercritical fluid extraction (SFE) in industrial processes has been increasing, mainly due to the environmental and quality factors involved: it is a process free of toxic waste, does not require extracts postprocessing to solvent removal and does not cause thermal extracts degradation, allows the low temperatures use, and prevents oxidation reactions, due to the light and oxygen absence on extraction column. Furthermore, it is a flexible process due to the continuous adjustment possibility of the solvent solvation power and selectivity [123-127].

The supercritical $\mathrm{CO}_{2}$ is an essential nonpolar solvent and its solvation power varies with its density. It permits extracting a large variety of lipophilic compounds depending on the pressure applied [128], such as carotenoids. The solute solubility in the supercritical fluid increases with the operating pressure at a constant temperature by increasing the density of the solvent. When increasing the pressure, the solute solubility also increases, but solvent selectivity is reduced [113].

The supercritical extraction can be an alternative to conventional methods for carotenoids extraction [116] and can be used with the pure supercritical solvent, usually $\mathrm{CO}_{2}$, or with addition of a cosolvent.

5.3.1. SFE with Pure $\mathrm{CO}_{2}$. De França et al. [14] performed the extraction of $\beta$-carotene from buriti (Mauritia flexuosa) pulp with supercritical $\mathrm{CO}_{2}$ to obtain high-concentrated oil fractions in this carotenoid. The results indicated that the supercritical $\mathrm{CO}_{2}$ at $20 \mathrm{MPa}$ of pressure and temperature of $40^{\circ} \mathrm{C}$ is capable of removing approximately $80 \%$ of the beta-carotene content in relation to the total amount extracted with hexane.

Mendes et al. [15] performed the SFE of lipids and carotenoids of microalgae Chlorella vulgaris in temperatures of 40 and $55^{\circ} \mathrm{C}$ and pressures from 15 to $35 \mathrm{MPa}$. Both the lipid contents such as carotenoids increased with elevating pressure. A few years later, the authors [16] expanded the research for 4 microalgae (Botryococcus braunii, Chlorella vulgaris, Dunaliella salina, and Arthrospira maxima) with the objective of maximizing the extraction of carotenoids and other lipids by SFE with $\mathrm{CO}_{2}$. SFE experiments were conducted at temperatures of 40 and $60^{\circ} \mathrm{C}$ and pressures from 10 to $35 \mathrm{MPa}$. As a result, the authors reported that at $40^{\circ} \mathrm{C}$ and $20 \mathrm{MPa}$ the microalgae Botryococcus braunii produced a supercritical gold and clear extract when compared to the extract obtained by conventional extraction. For the microalgae Chlorella vulgaris, the SFE produced extracts composed by canthaxanthin and astaxanthin, and the carotenoids yield was higher when increasing pressure. As for the algae Dunaliella salina, which produces $\beta$-carotene in high yields, the results indicate that the cis-isomer of this carotenoid is much more soluble in supercritical $\mathrm{CO}_{2}$ at $30 \mathrm{MPa}$ and $40^{\circ} \mathrm{C}$. Finally, for the cyanobacteria Arthrospira maxima, the main lipid was identified as $\gamma$-linolenic acid.

Macías-Sánchez et al. [17] conducted the SFE of carotenoids and chlorophyll from marine microalgae Nannochloropsis gaditana. For this, they evaluated the influence of temperature $\left(40\right.$ to $60^{\circ} \mathrm{C}$ ) and pressure (from 10 to $50 \mathrm{MPa}$ ), obtaining empirical relationships between carotenoids and chlorophyll yields, according to the operational parameters. The results showed that it is necessary to work in pressure of $40 \mathrm{MPa}$ at $60^{\circ} \mathrm{C}$ to obtain a significant yield of the pigments evaluated.

Macías-Sánchez et al. [18] carried out the extraction with supercritical $\mathrm{CO}_{2}$ from dry biomass of the cyanobacterium Synechococcus sp., in order to concentrate carotenoids and chlorophyll. The experiments conduced from 10 to $50 \mathrm{MPa}$ of pressure and from 40 to $60^{\circ} \mathrm{C}$ of temperature. The highest concentration of carotenoids was obtained at $30 \mathrm{MPa}$ and $50^{\circ} \mathrm{C}$, while the highest carotenoids/chlorophyll ratio was obtained at $20 \mathrm{MPa}$ and $60^{\circ} \mathrm{C}$, due to the highest selectivity achieved by facilitating the separation and purification of two pigments groups. According to the authors, the supercritical $\mathrm{CO}_{2}$ is an adequate solvent for carotenoids extraction due to the low polarity of these components and, then, the process becomes more selective in the presence of more polar pigments such as chlorophyll.

Machmudah et al. [19] performed the SFE of the rose fruit (Rosa canina) at pressures from 15 to $45 \mathrm{MPa}$, temperatures from 40 to $80^{\circ} \mathrm{C}$, and $\mathrm{CO}_{2}$ flow rate from 2 to $4 \mathrm{~mL} / \mathrm{min}$, in order to optimize the carotenoids extraction. The total carotenoids concentration from the rose fruit was from 10.35 to $20.88 \mathrm{mg} / \mathrm{g}$ of fruit, and the maximum concentration was obtained at $80^{\circ} \mathrm{C}, 45 \mathrm{MPa}$, and $4 \mathrm{~mL} / \mathrm{min}$. The main carotenoids present in the extracts were lycopene (1.18$14.37 \mathrm{mg} / \mathrm{g})$, the $\beta$-carotene $(0.154-1.017 \mathrm{mg} / \mathrm{g})$, and lutein (1.26-16.84 mg/g). Optimization results showed significant effects: the temperature in the total carotenoids yield; the temperature, pressure, and $\mathrm{CO}_{2}$ flow rate in the lycopene yield; and pressure and $\mathrm{CO}_{2}$ flow rate in the $\beta$-carotene and lutein yields.

Filho et al. [20] performed the carotenoids extraction using supercritical $\mathrm{CO}_{2}$ from pitanga (Eugenia uniflora L.). The conditions evaluated were two levels of temperature (40 and $\left.60^{\circ} \mathrm{C}\right)$ and seven levels of pressure $(10,15,20,25,30$, 35 , and $40 \mathrm{MPa})$. The major carotenoids identified in the supercritical extracts were lycopene, the rubixanthin, and 
$\beta$-cryptoxanthin, and the maximum carotenoids recovery (55\%) was obtained at $60^{\circ} \mathrm{C}$ and $25 \mathrm{MPa}$, focusing mainly on lycopene (78\%) and rubixanthin (74\%). The different operating conditions established different extracts composition according to the SFE yield and carotenoids concentration, indicating that supercritical $\mathrm{CO}_{2}$ is selective depending on the temperature and pressure.

de la Fuente et al. [129] studied the lycopene and astaxanthin solubility in supercritical $\mathrm{CO}_{2}$ as a function of temperature $\left(40\right.$ to $\left.60^{\circ} \mathrm{C}\right)$ and pressure $(10$ to $42 \mathrm{MPa})$. The results indicated that, in general, both the lycopene and astaxanthin solubilities in supercritical $\mathrm{CO}_{2}$ were higher when pressure and temperature were elevated, varying from 0.28 to $1.5 \times 10^{-6}$ for lycopene and from 0,01 to $1.2 \times 10^{-6}$ for astaxanthin.

Mezzomo et al. [31] studied the technical and the economical viability to concentrate the carotenoid components by means of SFE from pink shrimp (P. paulensis and P. paulensis) processing waste. The variation of raw material moisture content (11.21 and 46.3\%), the solvent flow rate (8.3 and $13.3 \mathrm{~g} / \mathrm{min})$, and the conditions of temperature $\left(40\right.$ and $\left.60^{\circ} \mathrm{C}\right)$ and pressure $(10-30 \mathrm{MPa})$ were evaluated. The results, represented by total carotenoid content, carotenoid profile, astaxanthin yield, and UV-Vis scanning spectrometry of extracts indicated that the SFE was favorable at $13.3 \mathrm{~g} / \mathrm{min}$ of $\mathrm{CO}_{2}$ flow rate and at $11.21 \%$ of raw material moisture content. The highest astaxanthin yield was obtained by pure $\mathrm{CO}_{2}$ at $300 \mathrm{bar} /$ $333.15 \mathrm{~K}$, and the cost analysis suggested a more lucrative process.

Kha et al. [21] evaluated the particle size of the raw material and SFE time, after an enzymatic pretreatment, on the oil yield and carotenoids content in the resultant oil using supercritical $\mathrm{CO}_{2}$ extraction from Gac fruit (Momordica cochinchinensis Spreng) aril. The authors conclude that the carotenoids content enhanced by suitable particle size of $0.45 \mathrm{~mm}$ and extraction time of $120 \mathrm{~min}$, as well as the Gac oil, contains high amount of carotenoids, specially the beta-carotene and lycopene.

Espinosa-Pardo et al. [22] evaluated extracts obtained from peach palm fruit (Bactris gasipaes) using SFE, in terms of yield, total phenolic content, total flavonoids, total carotenoids, and antioxidant activity by $\beta$-carotene bleaching method. The authors concluded that supercritical $\mathrm{CO}_{2}$ allows for obtaining rich extracts in carotenoids and although it presents lower yield than conventional extraction, the SFE represents a technique with greater advantages. The best operation condition for SFE was $300 \mathrm{bar} / 40^{\circ} \mathrm{C}$, given that the highest concentration of carotenoids was obtained.

Goto et al. [23] developed a wet extraction process using liquefied (subcritical) dimethyl ether (DME) as solvent at around $59 \mathrm{MPa}$. They applied liquefied DME for the extraction of lipids and functional compounds, such as carotenoids, from various kinds of algae. The results indicated that since the water content of biomaterials was very high, drying process was necessary. Moreover, the subcritical (liquefied) DME is unique and suitable for extraction of water and oily substances from biomaterials with high water content. In addition, it can eliminate the process for cell disruption and solvent evaporation and, then, has potential to cut energy consumption of extraction procedures.

Algae contain lipids and functional compounds such as carotenoids. Particularly, microalgae are recently focused as a source of biofuel. To extract these components, organic solvent or supercritical carbon dioxide has been used.

5.3.2. SFE with $\mathrm{CO}_{2}+$ Cosolvent. One of the main characteristics of supercritical $\mathrm{CO}_{2}$ is that it presents a limited solvation power when used to polar solutes. The addition of an organic solvent as a modifier can enhance the $\mathrm{CO}_{2}$ efficiency by increasing the compound's solubility, reducing its interactions with the matrix, or changing it to simplify the extraction [130]. Hawthorne and Miller [130] stated that an effective cosolvent must be more polar than the supercritical solvent and a good solvent in the liquid state for the solute focused.

Lim et al. [24] studied the separation of astaxanthin from Phaffia rhodozyma by SFE with $\mathrm{CO}_{2}$ superficial flow rate varying from 0.27 to $0.54 \mathrm{~cm} / \mathrm{min}$, pressure from 10.2 to $50 \mathrm{MPa}$, temperature from 40 to $80^{\circ} \mathrm{C}$, and use of ethanol as cosolvent at concentrations from 1 to $15 \%$. The best carotenoids recovery (85\%) and astaxanthin (90\%) using pure $\mathrm{CO}_{2}$ at $0.54 \mathrm{~cm} / \mathrm{min}$ were obtained at $40^{\circ} \mathrm{C}$ and $50 \mathrm{MPa}$. The $15 \%$ ethanol showed an increase of astaxanthin yield of 9 and $24 \%$ at 40 and $60^{\circ} \mathrm{C}$, respectively, when operated at $50 \mathrm{MPa}$. When using two subsequent steps with pressures ranging from 30 to $50 \mathrm{MPa}$, the astaxanthin concentration on high pressure increased by 4 times at $40^{\circ} \mathrm{C}$ and 10 times at $60^{\circ} \mathrm{C}$, and the astaxanthin concentrations were 3.6 to 13 times greater than those obtained in conventional extraction using acetone.

Katherine et al. [25] conducted a study of supercritical $\mathrm{CO}_{2}$ as solvent and ethanol as cosolvent aiming to establish conditions to obtain maximum extraction of lycopene from frozen watermelon by varying the operating temperature $\left(70-90^{\circ} \mathrm{C}\right)$, pressure (20.7-41.4 MPa), and the ethanol concentration (10 to $15 \%)$. The results had the highest lycopene concentration obtained at lower temperature $\left(70^{\circ} \mathrm{C}\right)$ and pressure $(20.7 \mathrm{MPa})$ and using the highest concentration of cosolvent (15\%). However, this extraction yield was 2.7 times lower than that obtained with fresh fruit, indicating that the storage of the watermelon in the studied conditions causes a significant loss of lycopene. The temperature was the parameter that showed the greatest effect on lycopene yield and, considering the storage losses, the authors followed the study evaluating the lycopene yield on the SFE temperature (from 60 to $75^{\circ} \mathrm{C}$ ), pressure of $20.7 \mathrm{MPa}$, and the ethanol addition of $15 \%$, obtaining a lycopene yield at $60^{\circ} \mathrm{C}$ of $14 \%$ higher than $70^{\circ} \mathrm{C}$.

López et al. [26] made a comparison between the conventional extraction with acetone and supercritical fluid extraction, with pure $\mathrm{CO}_{2}$ or adding ethanol (5-20\%), of astaxanthin from crustaceans, at conditions of 20 to $35 \mathrm{MPa}$ and 40 to $60^{\circ} \mathrm{C}$ in a dynamic extraction during 15 to $25 \mathrm{~min}$. In a subsequent step, the column was depressurized and flushed with $1.5 \mathrm{~mL}$ of acetone. The highest astaxanthin yield was obtained at $20 \mathrm{MPa}$ and $60^{\circ} \mathrm{C}$, and the SFE time of $15 \mathrm{~min}$ was considered ideal to remove this pigment. The range of ethanol content studied was chosen according to the polarity 
of the component and determined by the SFE data from the literature. According to the authors, the ethanol addition was necessary to ensure a significant astaxanthin extraction, being that the optimum concentration was $15 \%$. Still, according to the authors, the SFE is simpler and faster than the conventional techniques of extraction, as well as being more efficient and accurate, and does not need to use large amounts of toxic solvents. In addition, the SFE extract can be obtained at low temperatures and, then, it is not exposed to thermal degradation.

Liau et al. [27] investigated cosolvent modified supercritical carbon dioxide extraction of lipids and carotenoids from the microalgae species of Nannochloropsis oculata. Continuous modification by ethanol of supercritical carbon dioxide extractions showed that the addition ratio was important for extraction efficiency of lipids and carotenoids. The extraction conducted at $35 \mathrm{MPa}, 50^{\circ} \mathrm{C}$, and $16.7 \%$ of ethanol addition yielded $7.61 \mathrm{mg} / \mathrm{g}$ of carotenoids.

As observed, ethanol, a polar solvent, has been used to increase the polarity of supercritical $\mathrm{CO}_{2}$ on the extraction of a wide variety of compounds. However, when the compounds to be extracted are nonpolar, as most carotenoids, this cosolvent is not the best option for increasing the solubility of $\mathrm{CO}_{2}$. In addition, the ethanol must be removed from the final product, requiring the use of heat and, thus, having the same disadvantages mentioned in the conventional extraction: postprocessing need and possible thermal degradation of the extract [29].

Otherwise, Bamberger et al. [131] reported that the solubility of less volatile lipids in supercritical $\mathrm{CO}_{2}$ is significantly increased by the presence of more triglycerides species on the system. According to Mendes et al. [15], to increase the extraction yield and protect the carotenoids from degradation, the addition of vegetable oil as cosolvent is an interesting alternative. Besides all the above advantages, Krichnavaruk et al. [30] cited that using vegetable oil as a modifier makes a subsequent separation of the oil product unnecessary. According to these considerations, the vegetable oil seems to be a good cosolvent in the SFE of carotenoids.

Vasapollo et al. [28] performed the lycopene extraction from tomato with supercritical $\mathrm{CO}_{2}$ added or not by vegetable oil (almond, peanut, hazelnut, and sunflower seed). The experiments were conducted evaluating the temperature (from 45 to $70^{\circ} \mathrm{C}$ ), pressure (from 33.5 to $45 \mathrm{MPa}$ ), and $\mathrm{CO}_{2}$ flow rate (from 8 to $20 \mathrm{~kg} / \mathrm{h}$ ). The hazelnut oil presented higher yields when compared to other oils and pure $\mathrm{CO}_{2}$; beyond that, it is cheaper and has less acidity, preventing the lycopene degradation during extraction. The highest lycopene concentration $(60 \%)$ of tomato was obtained at $45 \mathrm{MPa}$ and $66^{\circ} \mathrm{C}$ with the addition of hazelnut oil at a concentration of $10 \%$ and $\mathrm{CO}_{2}$ flow rate of $20 \mathrm{~kg} / \mathrm{h}$.

Sun and Temelli [29] evaluated the SFE efficiency on carotenoids extraction from carrot using canola oil as cosolvent, compared with conventional extraction using hexane and acetone. SFE experiments were conducted evaluating the effect of raw material moisture (0.8-84.6\%), particle size $(0.25-2 \mathrm{~mm})$, temperature $\left(40-70^{\circ} \mathrm{C}\right)$, pressure $(276-551$ bar), concentration of canola oil ( $0-5 \%)$, and $\mathrm{CO}_{2}$ flow rate $(0.5-2 \mathrm{~L} / \mathrm{min})$. When canola oil was added, the extraction yields of $\alpha$-and $\beta$-carotene increased more than twice those of lutein, and more than four times compared to the yield obtained with pure $\mathrm{CO}_{2}$. The increase of both temperature and pressure had a positive effect on carotenes yield, while larger particle sizes had a negative impact on carotenes yield. $\alpha$-Carotene and $\beta$-carotene yields decreased with increasing raw material moisture, while the lutein yield increased. The highest carotenoids yield was obtained in superior $\mathrm{CO}_{2}$ flow rate, but a greater variety of carotenoids was solubilized when the supercritical $\mathrm{CO}_{2}$ was used in the lower flow rate. Thus, the highest carotenoids yield was obtained at $70^{\circ} \mathrm{C}, 551 \mathrm{bar}$, $5 \%$ canola oil, particle diameter of $0.25-0.5 \mathrm{~mm}, 0.8 \%$ raw material moisture, and $2 \mathrm{~L} / \mathrm{min} \mathrm{CO}_{2}$ flow rate.

The effects of different modifiers on the compositions, yield, and antioxidant activity of carotenoid by SFE of pumpkin (Cucurbita maxima) were studied by Shi et al. [32]. The different concentrations of single, mixed binary or ternary modifiers were designed as follows: (1) single modifiers: ethanol $(5 \%, 10 \%$ or $15 \%)$, water $(5 \%, 10 \%$ or $15 \%)$, or oil $(5 \%$, $10 \%$ or $15 \%)$ and (2) mixed binary modifiers: ethanol $(5 \%$ or $10 \%)+$ water $(5 \%$ or $10 \%)$, water $(5 \%$ or $10 \%)+$ oil $(5 \%$ or $10 \%)$, or ethanol $(5 \%$ or $10 \%)+$ oil $(5 \%$ or $10 \%)$. The combination of ethanol and water, or ethanol and oil, or water and oil in SFE showed that the yields of carotenoids were higher than the single modifier with equal amount. Finally, authors concluded that the modifier and operating temperature of SFE notably influenced the selectivity of carotenoids, especially the ratio of cis-b-carotene/total carotenoids.

Krichnavaruk et al. [30] investigated the use of ethanol, soybean oil, or olive oil as cosolvents to the supercritical $\mathrm{CO}_{2}$ extraction of astaxanthin from Haematococcus pluvialis, in comparison with SFE using pure $\mathrm{CO}_{2}$. Without the addition of cosolvents, only $25 \%$ of astaxanthin was extracted under the conditions of $70^{\circ} \mathrm{C}$ and $40 \mathrm{MPa}$, whereas with the use of soybean oil and olive oil as cosolvent at a concentration of $10 \%$ achieved an increase of $30 \%$ and $80 \%$, respectively, of the efficiency of astaxanthin extraction. As the authors conclude, the results of their study clearly demonstrated the superiority power of extraction when using cosolvents, such as soybean oil and olive oil, in the high-pressure extraction of astaxanthin from $H$. pluvialis.

Table 1 summarized the information of mentioned works that applied the SFE for carotenoid extraction.

\section{Final Comments}

Brazil has an underused agricultural potential with a variety of fruits and vegetables species low or inadequately investigated. This could potentially demonstrate an increase in the range of possible sources of carotenoids with broad utility in food, cosmetics, and medicines.

Different microorganisms and bioproduction techniques are being developed, as well as extraction methods of these compounds, aiming to improve the process by the determination of ideal operating conditions to reach an optimum yield of carotenoids depending on the matrix.

More optimization studies and also validation methods are required to pursue the performance of technical studies to 
TABLE 1: Information about recent studies focusing on the supercritical fluid extraction of carotenoids from natural materials.

\begin{tabular}{|c|c|c|c|c|}
\hline Raw material & Solvent applied & Pressure and temperature applied & Carotenoid of interest & Reference \\
\hline Buriti (M. flexuosa) pulp & Carbon dioxide & 20 and $30 \mathrm{MPa}, 40$ and $55^{\circ} \mathrm{C}$ & $\beta$-Carotene & {$[14]$} \\
\hline C. vulgaris & Carbon dioxide & 15 and $35 \mathrm{MPa}, 40$ and $55^{\circ} \mathrm{C}$ & $\begin{array}{l}\text { Canthaxanthin and } \\
\text { astaxanthin }\end{array}$ & {$[15]$} \\
\hline $\begin{array}{l}\text { C. vulgaris, D. salina, and } \\
\text { A. maxima }\end{array}$ & Carbon dioxide & $10-35 \mathrm{MPa}, 40$ and $60^{\circ} \mathrm{C}$ & $\begin{array}{c}\text { Total carotenoid content, } \\
\beta \text {-carotene }\end{array}$ & {$[16]$} \\
\hline Nannochloropsis gaditana & Carbon dioxide & $10-50 \mathrm{MPa}, 40-60^{\circ} \mathrm{C}$ & Total carotenoid content & [17] \\
\hline Synechococcus sp. & Carbon dioxide & $10-50 \mathrm{MPa}, 40-60^{\circ} \mathrm{C}$ & Total carotenoid content & {$[18]$} \\
\hline Rose fruit (R. canina) & Carbon dioxide & $15-45 \mathrm{MPa}, 40-80^{\circ} \mathrm{C}$ & $\begin{array}{c}\text { Total carotenoid content, } \\
\text { lycopene, } \beta \text {-carotene, and } \\
\text { lutein }\end{array}$ & {$[19]$} \\
\hline Pitanga fruit (E. uniflora L.) & Carbon dioxide & $10-40 \mathrm{MPa}, 40$ and $60^{\circ} \mathrm{C}$ & $\begin{array}{c}\text { Total carotenoid content, } \\
\text { lycopene, rubixanthin and } \\
\beta \text {-cryptoxanthin }\end{array}$ & {$[20]$} \\
\hline $\begin{array}{l}\text { Gac fruit } \\
\text { (Momordica cochinchinensis } \\
\text { Spreng) aril }\end{array}$ & Carbon dioxide & $20 \mathrm{MPa}, 50^{\circ} \mathrm{C}$ & $\beta$-carotene, lycopene & {$[21]$} \\
\hline $\begin{array}{l}\text { Peach palm pulp } \\
\text { (Bactrisgasipaes) }\end{array}$ & Carbon dioxide & $10-30 \mathrm{MPa}, 40-60^{\circ} \mathrm{C}$ & Total carotenoid content & {$[22]$} \\
\hline $\begin{array}{l}\text { Japanese algae } \\
\text { (Chlorella vulgaris, } \\
\text { Undaria pinnatifida) }\end{array}$ & Dimethyl ether & $20-50 \mathrm{MPa}, 40-80^{\circ} \mathrm{C}$ & Fucoxanthin & {$[23]$} \\
\hline Phaffia rhodozyma & Carbon dioxide + ethanol & $10.2-50 \mathrm{MPa}, 40-80^{\circ} \mathrm{C}$ & $\begin{array}{c}\text { Total carotenoid content, } \\
\text { astaxanthin }\end{array}$ & {$[24]$} \\
\hline Frozen watermelon & Carbon dioxide + ethanol & 20.7-41.4 MPa, $70-90^{\circ} \mathrm{C}$ & Lycopene & {$[25]$} \\
\hline Crustaceans & Carbon dioxide + ethanol & $20-35 \mathrm{MPa}, 40-60^{\circ} \mathrm{C}$ & Astaxanthin & {$[26]$} \\
\hline Nannochloropsis oculata & Carbon dioxide + ethanol & $35 \mathrm{MPa}, 50^{\circ} \mathrm{C}$ & Total carotenoid content & {$[27]$} \\
\hline Tomato & $\begin{array}{c}\text { Carbon dioxide }+ \text { several } \\
\text { vegetal oils }\end{array}$ & $33.5-45 \mathrm{MPa}, 45-70^{\circ} \mathrm{C}$ & Lycopene & {$[28]$} \\
\hline Carrot & Carbon dioxide + canola oil & $27.6-55.1 \mathrm{MPa}, 40-70^{\circ} \mathrm{C}$ & $\begin{array}{l}\text { Total carotenoid content, } \alpha \text { - } \\
\text { and } \beta \text {-carotene, and lutein }\end{array}$ & {$[29]$} \\
\hline Haematococcus pluvialis & $\begin{array}{c}\text { Carbon dioxide, carbon } \\
\text { dioxide + ethanol, and } \\
\text { carbon dioxide + vegetal } \\
\text { oils }\end{array}$ & $40 \mathrm{MPa}, 70^{\circ} \mathrm{C}$ & Astaxanthin & {$[30]$} \\
\hline $\begin{array}{l}\text { Pink shrimp ( } P \text {. paulensis } \\
\text { and } P \text {. paulensis) processing } \\
\text { waste }\end{array}$ & $\begin{array}{c}\text { Carbon dioxide, carbon } \\
\text { dioxide }+ \\
\text { hexane/isopropanol } \\
\text { mixture, and carbon } \\
\text { dioxide }+ \text { sunflower oil } \\
\end{array}$ & $10-30 \mathrm{MPa}, 40$ and $60^{\circ} \mathrm{C}$ & $\begin{array}{c}\text { Total carotenoid content, } \\
\text { carotenoid profile, and } \\
\text { astaxanthin }\end{array}$ & {$[31]$} \\
\hline $\begin{array}{l}\text { Pumpkin } \\
\text { (Cucurbita maxima) }\end{array}$ & $\begin{array}{c}\text { Carbon dioxide + ethanol, } \\
\text { water and/or olive oil }\end{array}$ & $25 \mathrm{MPa}, 50$ and $80^{\circ} \mathrm{C}$ & $\begin{array}{l}\text { Total carotenoid content, } \\
\text { carotenoid profile }\end{array}$ & {$[32]$} \\
\hline
\end{tabular}

scale up the processes and the determination of their economical viability, which are essential to reach industrial production and, thus, the consumer.

Thus, the functional and nutritional benefits of these natural pigments (such as precursors of vitamin A in the treatment of diseases like cancer through its antioxidant activity, among others) and their coloring properties must be effectively achieved and applied.

\section{Competing Interests}

The authors declare that they have no competing interests.

\section{Acknowledgments}

The authors wish to thank CNPq, Project no. 454025/20149, and CAPES, Project no. 23038.007787/2011-70 (AUXPE: $2516 / 2011$ ), Brazilian funding agencies, for the financial support and scholarships that sustain this work.

\section{References}

[1] J. G. Bell, J. McEvoy, D. R. Tocher, and J. R. Sargent, "Depletion of $\alpha$-tocopherol and astaxanthin in Atlantic salmon (Salmo salar) affects autoxidative defense and fatty acid metabolism," Journal of Nutrition, vol. 130, no. 7, pp. 1800-1808, 2000. 
[2] P. Botella-Pavía and M. Rodríguez-Concepción, "Carotenoid biotechnology in plants for nutritionally improved foods," Physiologia Plantarum, vol. 126, no. 3, pp. 369-381, 2006.

[3] J. Oliver and A. Palou, "Chromatographic determination of carotenoids in foods," Journal of Chromatography A, vol. 881, no. 1-2, pp. 543-555, 2000.

[4] G. Britton, S. Liaaen-Jensen, and H. Pfander, Carotenoids Hand Book, Birkhäuser, Basel, Switzerland, 2004.

[5] P. Y. Niizu, Fontes de Carotenóides Importantes para a Saúde Humana [Mastering thesis (Food Science)], Faculdade de Engenharia de Alimentos, Universidade Estadual de Campinas (UNICAMP), Campinas, Brazil, 2003.

[6] N. Mezzomo, L. Tenfen, M. S. Farias, M. T. Friedrich, R. C. Pedrosa, and S. R. S. Ferreira, "Evidence of antiobesity and mixed hypolipidemic effects of extracts from pink shrimp (Penaeus brasiliensis and Penaeus paulensis) processing residue," Journal of Supercritical Fluids, vol. 96, pp. 252-261, 2015.

[7] C. L. B. Ambrósio, F. de Arruda Camara e Siqueira Campos, and Z. P. de Faro, "Carotenóides como alternativa contra a hipovitaminose A," Revista de Nutrição, vol. 19, no. 2, pp. 233243, 2006.

[8] P. G. B. Carvalho, C. M. M. Machado, C. L. Moretti, and M. E. N. Fonseca, "Hortaliças como alimentos funcionais," Horticultura Brasileira, vol. 24, no. 4, pp. 397-404, 2006.

[9] B. L. Pool-Zobel, A. Bub, H. Müller, I. Wollowski, and G. Rechkemmer, "Consumption of vegetables reduces genetic damage in humans: first results of a human intervention trial with carotenoid-rich foods," Carcinogenesis, vol. 18, no. 9, pp. 1847-1850, 1997.

[10] N. J. I. E. Shami and E. A. M. Moreira, "Licopeno como agente antioxidante," Revista de Nutrição, vol. 17, no. 2, pp. 227-236, 2004.

[11] A. M. Papas, "Diet and antioxidant status," Food and Chemical Toxicology, vol. 37, no. 9-10, pp. 999-1007, 1999.

[12] J. A. Olson, "Carotenoids and human health," Archivos Latinoamericanos de Nutricion, vol. 49, no. 3, supplement 1, pp. 7S11S, 1999.

[13] J. W. Erdman Jr., "Variable bioavailability of carotenoids from vegetables," American Journal of Clinical Nutrition, vol. 70, no. 2, pp. 179-180, 1999.

[14] L. F. De França, G. Reber, M. A. A. Meireles, N. T. Machado, and G. Brunner, "Supercritical extraction of carotenoids and lipids from buriti (Mauritia flexuosa), a fruit from the Amazon region," The Journal of Supercritical Fluids, vol. 14, no. 3, pp. 247256, 1999.

[15] R. L. Mendes, H. L. Fernandes, J. Coelho et al., "Supercritical $\mathrm{CO}_{2}$ extraction of carotenoids and other lipids from Chlorella vulgaris," Food Chemistry, vol. 53, no. 1, pp. 99-103, 1995.

[16] R. L. Mendes, B. P. Nobre, M. T. Cardoso, A. P. Pereira, and A. F. Palavra, "Supercritical carbon dioxide extraction of compounds with pharmaceutical importance from microalgae," Inorganica Chimica Acta, vol. 356, pp. 328-334, 2003.

[17] M. D. Macías-Sánchez, C. Mantell, M. Rodríguez, E. Martínez De La Ossa, L. M. Lubián, and O. Montero, "Supercritical fluid extraction of carotenoids and chlorophyll a from Nannochloropsis gaditana," Journal of Food Engineering, vol. 66, no. 2, pp. 245251, 2005.

[18] M. D. Macías-Sánchez, C. Mantell, M. Rodríguez, E. Martínez de la Ossa, L. M. Lubián, and O. Montero, "Supercritical fluid extraction of carotenoids and chlorophyll a from Synechococcus sp.," The Journal of Supercritical Fluids, vol. 39, no. 3, pp. 323329, 2007.

[19] S. Machmudah, Y. Kawahito, M. Sasaki, and M. Goyo, "Process optimization and extraction rate analysis of carotenoids extraction from rosehip fruit using $\mathrm{SC}-\mathrm{CO}_{2}$," The Journal of Supercritical Fluids, vol. 44, no. 3, pp. 308-314, 2008.

[20] G. L. Filho, V. V. De Rosso, M. A. A. Meireles et al., "Supercritical $\mathrm{CO}_{2}$ extraction of carotenoids from pitanga fruits (Eugenia uniflora L.)," The Journal of Supercritical Fluids, vol. 46, no. 1, pp. 33-39, 2008.

[21] T. C. Kha, H. Phan-Tai, and M. H. Nguyen, "Effects of pretreatments on the yield and carotenoid content of Gac oil using supercritical carbon dioxide extraction," Journal of Food Engineering, vol. 120, no. 1, pp. 44-49, 2014.

[22] F. A. Espinosa-Pardo, J. Martinez, and H. A. Martinez-Correa, "Extraction of bioactive compounds from peach palm pulp (Bactris gasipaes) using supercritical $\mathrm{CO}_{2}$," Journal of Supercritical Fluids, vol. 93, pp. 2-6, 2014.

[23] M. Goto, H. Kanda, Wahyudiono, and S. Machmudah, "Extraction of carotenoids and lipids from algae by supercritical $\mathrm{CO}_{2}$ and subcritical dimethyl ether," The Journal of Supercritical Fluids, vol. 96, pp. 245-251, 2015.

[24] G.-B. Lim, S.-Y. Lee, E.-K. Lee, S.-J. Haam, and W.-S. Kim, "Separation of astaxanthin from red yeast Phaffia rhodozyma by supercritical carbon dioxide extraction," Biochemical Engineering Journal, vol. 11, no. 2-3, pp. 181-187, 2002.

[25] L. S. V. Katherine, C. C. Edgar, W. King Jerry, R. Howard Luke, and C. D. Julie, "Extraction conditions affecting supercritical fluid extraction (SFE) of lycopene from watermelon," Bioresource Technology, vol. 99, no. 16, pp. 7835-7841, 2008.

[26] M. López, L. Arce, J. Garrido, A. Ríos, and M. Valcárcel, “Selective extraction of astaxanthin from crustaceans by use of supercritical carbon dioxide," Talanta, vol. 64, no. 3, pp. 726-731, 2004.

[27] B.-C. Liau, C.-T. Shen, F.-P. Liang et al., "Supercritical fluids extraction and anti-solvent purification of carotenoids from microalgae and associated bioactivity," The Journal of Supercritical Fluids, vol. 55, no. 1, pp. 169-175, 2010.

[28] G. Vasapollo, L. Longo, L. Rescio, and L. Ciurlia, "Innovative supercritical $\mathrm{CO}_{2}$ extraction of lycopene from tomato in the presence of vegetable oil as co-solvent," The Journal of Supercritical Fluids, vol. 29, no. 1-2, pp. 87-96, 2004.

[29] M. Sun and F. Temelli, "Supercritical carbon dioxide extraction of carotenoids from carrot using canola oil as a continuous cosolvent," The Journal of Supercritical Fluids, vol. 37, no. 3, pp. 397-408, 2006.

[30] S. Krichnavaruk, A. Shotipruk, M. Goto, and P. Pavasant, "Supercritical carbon dioxide extraction of astaxanthin from Haematococcus pluvialis with vegetable oils as co-solvent," Bioresource Technology, vol. 99, no. 13, pp. 5556-5560, 2008.

[31] N. Mezzomo, J. Martínez, M. Maraschin, and S. R. S. Ferreira, "Pink shrimp (P. brasiliensis and P. paulensis) residue: supercritical fluid extraction of carotenoid fraction," The Journal of Supercritical Fluids, vol. 74, pp. 22-33, 2013.

[32] X. Shi, H. Wu, J. Shi et al., "Effect of modifier on the composition and antioxidant activity of carotenoid extracts from pumpkin (Cucurbita maxima) by supercritical $\mathrm{CO}_{2}$, , LWT-Food Science and Technology, vol. 51, no. 2, pp. 433-440, 2013.

[33] M. K. Kim, S. H. Ahn, and Y. C. Lee-Kim, "Relationship of serum $\alpha$-tocopherol, carotenoids and retinol with the risk of breast cancer," Nutrition Research, vol. 21, no. 6, pp. 797-809, 2001. 
[34] I. R. Maldonade, A. R. P. Scamparini, and D. B. RodriguezAmaya, "Selection and characterization of carotenoid-producing yeasts from Campinas region, Brazil," Brazilian Journal of Microbiology, vol. 38, no. 1, pp. 65-70, 2007.

[35] P. Bhosale, "Environmental and cultural stimulants in the production of carotenoids from microorganisms," Applied Microbiology and Biotechnology, vol. 63, no. 4, pp. 351-361, 2004.

[36] Z. Aksu and A. T. Eren, "Carotenoids production by the yeast Rhodotorula mucilaginosa: use of agricultural wastes as a carbon source," Process Biochemistry, vol. 40, no. 9, pp. 2985-2991, 2005.

[37] W. A. Schroeder and E. A. Johnson, "Singlet oxygen and peroxyl radicals regulate carotenoid biosynthesis in Phaffia rhodozyma," The Journal of Biological Chemistry, vol. 270, no. 31, pp. 1837418379, 1995.

[38] C. Thane and S. Reddy, "Processing of fruit and vegetables: effect on carotenoids," Nutrition \& Food Science, vol. 97, no. 2, pp. 5865, 1997.

[39] E. Marasco and C. Schmidt-Dannert, "Towards the biotechnological production of aroma and flavor compounds in engineered microorganisms," Applied Biotechnology Food Science and Policy, vol. 1, no. 3, pp. 145-157, 2003.

[40] H. Klaui and J. C. Bauernfeind, "Carotenoids as food colors," in Carotenoids and Colorants and vitamin a Precursors, J. C. Bauernfeind, Ed., p. 156, Academic Press, New York, NY, USA, 1981.

[41] T. R. Omara-Alwala, H.-M. Chen, Y. Ito, K. L. Simpson, and S. P. Meyers, "Carotenoid pigment and fatty acid analyses of crawfish oil extracts," Journal of Agricultural and Food Chemistry, vol. 33, no. 2, pp. 260-263, 1985.

[42] A. Guillou, M. Khalil, and L. Adambounou, "Effects of silage preservation on astaxanthin forms and fatty acid profiles of processed shrimp (Pandalus borealis) waste," Aquaculture, vol. 130, no. 4, pp. 351-360, 1995.

[43] E. Wathne, B. Bjerkeng, T. Storebakken, V. Vassvik, and A. B. Odland, "Pigmentation of Atlantic Salmon (Salmo salar) fed astaxanthin in all meals or in alternating meals," Aquacultlure, vol. 159, pp. 217-231, 1998.

[44] P. Tatsch, Produção de carotenóides em meio sintético por Sporidiobolus salmonicolor cbs $2636 \mathrm{em}$ biorreator [M.S. thesis], (Food Engineering). Faculdade de Engenharia de Alimentos, Universidade Regional do Alto Uruguai (URI), Erechim, Brazil, 2008.

[45] J. Gross, Pigments in Vegetables: Chlorophylls and Carotenoids, Van Nostrand Reinhold Company, New York, NY, USA, 1991.

[46] C. R. Gale, H. E. Ashurst, H. J. Powers, and C. N. Martyn, "Antioxidant vitamin status and carotid atherosclerosis in the elderly," American Journal of Clinical Nutrition, vol. 74, no. 3, pp. 402-408, 2001.

[47] S. K. Osganian, M. J. Stampfer, E. Rimm, D. Spiegelman, J. E. Manson, and W. C. Willett, "Dietary carotenoids and risk of coronary artery disease in women," American Journal of Clinical Nutrition, vol. 77, no. 6, pp. 1390-1399, 2003.

[48] J. Carper, Alimentos: o melhor remédio para a boa saúde, Campus, Rio de Janeiro, Brazil, 1995.

[49] A. V. Rao, "Lycopene, tomatoes, and the prevention of coronary heart disease," Experimental Biology and Medicine, vol. 227, no. 10, pp. 908-913, 2002.

[50] A. V. Rao, Z. Waseem, and S. Agarwal, "Lycopene content of tomatoes and tomato products and their contribution to dietary lycopene," Food Research International, vol. 31, no. 10, pp. 737741, 1998.
[51] A. V. Rao and S. Agarwal, "Role of antioxidant lycopene in cancer and heart disease," Journal of the American College of Nutrition, vol. 19, no. 5, pp. 563-569, 2000.

[52] S. K. Clinton, "Lycopene: chemistry, biology, and implications for human health and disease," Nutrition Reviews, vol. 56, no. 2, pp. 35-51, 1998.

[53] J. Shi, M. L. Maguer, Y. Kakuda, A. Liptay, and F. Niekamp, "Lycopene degradation and isomerization in tomato dehydration," Food Research International, vol. 32, no. 1, pp. 15-21, 1999.

[54] M. L. Nguyen and S. J. Schwartz, "Lycopene: chemical and biological properties," Food Technology, vol. 53, no. 2, pp. 3845, 1999.

[55] D. W. Cramer, H. Kuper, B. L. Harlow, and L. Titus-Ernstoff, "Carotenoids, antioxidants and ovarian cancer risk in pre- and postmenopausal women," International Journal of Cancer, vol. 94, no. 1, pp. 128-134, 2001.

[56] T. W.-M. Boileau, Z. Liao, S. Kim, S. Lemeshow, J. W. Erdman Jr., and S. K. Clinton, "Prostate carcinogenesis in N-methyl-Nnitrosourea (NMU)-testosterone-treated rats fed tomato powder, lycopene, or energy-restricted diets," Journal of the National Cancer Institute, vol. 95, no. 21, pp. 1578-1586, 2003.

[57] S. M. Moeller, P. F. Jacques, and J. B. Blumberg, “The potential role of dietary xanthophylls in cataract and age-related macular degeneration," Journal of the American College of Nutrition, vol. 19, no. 5, pp. 522S-527S, 2000.

[58] M. P. Pangantihon-Kühlmann, O. Millamena, and Y. Chern, "Effect of dietary astaxanthin and vitamin A on the reproductive performance of Penaeus monodon broodstock," Aquatic Living Resources, vol. 11, no. 6, pp. 403-409, 1998.

[59] Z.-C. Hu, Y.-G. Zheng, Z. Wang, and Y.-C. Shen, "pH control strategy in astaxanthin fermentation bioprocess by Xanthophyllomyces dendrorhous," Enzyme and Microbial Technology, vol. 39, no. 4, pp. 586-590, 2006.

[60] B. K. Simpson, G. Nayeri, V. Yaylayan, and I. N. A. Ashie, "Enzymatic hydrolysis of shrimp meat," Food Chemistry, vol. 61, no. 1-2, pp. 131-138, 1998.

[61] H. M. Chen and S. Meyers, "Ensilage treatment of crawfish waste for improvement of astaxanthin pigment extraction," Journal of Food Science, vol. 48, no. 5, pp. 1516-1520, 1982.

[62] S. P. Meyers and D. Bligh, "Characterization of astaxanthin pigments from heat-processed crawfish waste," Journal of Agricultural and Food Chemistry, vol. 29, no. 3, pp. 505-508, 1981.

[63] A. R.-B. de Quirós and H. S. Costa, "Analysis of carotenoids in vegetable and plasma samples: a review," Journal of Food Composition and Analysis, vol. 19, no. 2-3, pp. 97-111, 2006.

[64] G. Sandmann, M. Albrecht, G. Schnurr, O. Knörzer, and P. Böger, "The biotechnological potential and design of novel carotenoids by gene combination in Escherichia coli," Trends in Biotechnology, vol. 17, no. 6, pp. 233-237, 1999.

[65] M. Sugiura, M. Nakamura, Y. Ikoma et al., "Serum carotenoid concentrations are inversely associated with serum aminotransferases in hyperglycemic subjects," Diabetes Research and Clinical Practice, vol. 71, no. 1, pp. 82-91, 2006.

[66] H. T. Godoy and D. B. Rodriguez-Amaya, "Buriti (Mauritia vinifera Mart.) uma fonte riquíssima de pró-vitamina A," Arquivos de Biologia e Tecnologia, vol. 38, pp. 109-120, 1995.

[67] P. A. Hiani and M. V. C. Penteado, "Carotenóides e valores de vitamina A do fruto e da farinha de bocaiúva (Acrocomia mokayáyba Barb. Rodr.) do Estado de Mato Grosso do Sul," Revista Farmacêutica Bioquímica da Universidade de São Paulo, vol. 25, pp. 158-168, 1989. 
[68] H. T. Godoy and D. B. Rodriguez-Amaya, "Carotenoid composition of comercial mangoes from Brazil," LebensmittelWissenschaft \& Technologie, vol. 22, pp. 100-103, 1989.

[69] H. K. Arima and D. B. Rodríguez-Amaya, "Carotenoid composition and vitamin A value of a squash and a pumpkin from northeastern Brazil," Archivos Latinoamericanos de Nutricion, vol. 40, no. 2, pp. 284-292, 1990.

[70] H. T. Godoy and D. B. Rodriguez-Amaya, "Occurence of cisisomers of provitamin A in Brazilian vegetables," Journal of Agricultural and Food Chemistry, vol. 46, no. 8, pp. 3081-3086, 1998.

[71] R. B. Assunção and A. Z. Mercadante, "Carotenoids and ascorbic acid composition from commercial products of cashew apple (Anacardium occidentale L.)," Journal of Food Composition and Analysis, vol. 16, no. 6, pp. 647-657, 2003.

[72] C. F. Zanatta and A. Z. Mercadante, "Carotenoid composition from the Brazilian tropical fruit camu-camu (Myrciaria dubia)," Food Chemistry, vol. 101, no. 4, pp. 1526-1532, 2007.

[73] M. Fikselová, S. Šilhár, J. Mareček, and H. Frančáková, "Extraction of carrot (Daucus carota L.) carotenes under different conditions," Czech Journal of Food Sciences, vol. 26, no. 4, pp. 268-274, 2008.

[74] A. Stoica, T. Dobre, M. Stroescu, A. Sturzoiu, and O. C. Pârvulescu, "From laboratory to scale-up by modelling in two cases of $\beta$-carotene extraction from vegetable products," Food and Bioproducts Processing, vol. 94, no. 4, pp. 218-228, 2015.

[75] J. A. Trujillo-Quijano, D. B. Rodriguez-Amaya, W. Esteves, and G. F. Plonis, "Carotenoid composition and vitamin A values of oils from Brazilian palm fruits," Lipid/Fett, vol. 92, no. 6, pp. 222-226, 1990.

[76] C. A. Tavares and D. B. Rodriguez-Amaya, "Carotenoid composition of Brazilian tomato products," LWT-Food Science and Technology, vol. 27, no. 3, pp. 219-224, 1994.

[77] M. M. Poojary and P. Passamonti, "Optimization of extraction of high purity all-trans-lycopene from tomato pulp waste," Food Chemistry, vol. 188, pp. 84-91, 2015.

[78] I. F. Strati, E. Gogou, and V. Oreopoulou, "Enzyme and high pressure assisted extraction of carotenoids from tomato waste," Food and Bioproducts Processing, vol. 94, pp. 668-674, 2015.

[79] K. K. H. Y. Ho, M. G. Ferruzzi, A. M. Liceaga, and M. F. San Martín-González, "Microwave-assisted extraction of lycopene in tomato peels: Effect of extraction conditions on all-trans and cis-isomer yields," LWT-Food Science and Technology, vol. 62, no. 1, pp. 160-168, 2015.

[80] M. Padula and D. B. Rodriguez-Amaya, "Characterisation of the carotenoids and assessment of the vitamin A value of Brasilian guavas (Psidium guajava L.)," Food Chemistry, vol. 20, no. 1, pp. 11-19, 1986.

[81] P. Y. Niizu and D. B. Rodriguez-Amaya, "A melancia como fonte de licopeno," in Proceedings of the 4th Brazilian Meeting on Chemistry of Food and Beverages, Campinas, Brazil, October 2002.

[82] M. Kimura, D. B. Rodriguez-Amaya, and S. M. Yokoyama, "Cultivar differences and geographic effects in the carotenoid composition and vitamin A value of papaya," Lebens Wissen Technology, vol. 24, pp. 415-418, 1991.

[83] V. V. de Rosso and A. Z. Mercadante, "Carotenoid composition of two Brazilian genotypes of acerola (Malpighia punicifolia L.) from two harvests," Food Research International, vol. 38, no. 8-9, pp. 1073-1077, 2005.
[84] M. Kimura and D. B. Rodriguez-Amaya, "Carotenoid composition of hydroponic leafy vegetables," Journal of Agricultural and Food Chemistry, vol. 51, no. 9, pp. 2603-2607, 2003.

[85] P. S. Hamano and A. Z. Mercadante, "Composition of carotenoids from commercial products of caja (Spondias lutea)," Journal of Food Composition and Analysis, vol. 14, no. 4, pp. 335343, 2001.

[86] E. Luengo, J. M. Martínez, A. Bordetas, I. Álvarez, and J. Raso, "Influence of the treatment medium temperature on lutein extraction assisted by pulsed electric fields from Chlorella vulgaris," Innovative Food Science \& Emerging Technologies, vol. 29, pp. 15-22, 2015.

[87] C. Chen, Jesisca, C. Hsieh, D. Lee, C. Chang, and J. Chang, "Production, extraction and stabilization of lutein from microalga Chlorella sorokiniana MB-1," Bioresource Technology, vol. 200, pp. 500-505, 2016.

[88] M.-C. Chan, S.-H. Ho, D.-J. Lee, C.-Y. Chen, C.-C. Huang, and J.-S. Chang, "Characterization, extraction and purification of lutein produced by an indigenous microalga Scenedesmus obliquus CNW-N," Biochemical Engineering Journal, vol. 78, pp. 24-31, 2013.

[89] D. Singh, C. J. Barrow, A. S. Mathur, D. K. Tuli, and M. Puri, "Optimization of zeaxanthin and $\beta$-carotene extraction from Chlorella saccharophila isolated from New Zealand marine waters," Biocatalysis and Agricultural Biotechnology, vol. 4, pp. 166-173, 2015.

[90] N. Mezzomo, B. Maestri, R. L. dos Santos, M. Maraschin, and S. R. S. Ferreira, "Pink shrimp (P. brasiliensis and P. paulensis) residue: influence of extraction method on carotenoid concentration," Talanta, vol. 85, no. 3, pp. 1383-1391, 2011.

[91] B. R. Parjikolaei, R. B. El-Houri, X. C. Fretté, and K. V. Christensen, "Influence of green solvent extraction on carotenoid yield from shrimp (Pandalus borealis) processing waste," Journal of Food Engineering, vol. 155, pp. 22-28, 2015.

[92] C. Yin, S. Yang, X. Liu, and H. Yan, "Efficient extraction of astaxanthin from phaffia rhodozyma with polar and non-polar solvents after acid washing," Chinese Journal of Chemical Engineering, vol. 21, no. 7, pp. 776-780, 2013.

[93] D. Y. Kim, D. Vijayan, R. Praveenkumar et al., "Cell-wall disruption and lipid/astaxanthin extraction from microalgae: Chlorella and Haematococcus," Bioresource Technology, vol. 199, pp. 300-310, 2016.

[94] M. C. Silva, Alterações na biossíntese de carotenóides em leveduras induzidas por agentes químicos [Doctoring Thesis (Food Science)], Faculdade de Engenharia de Alimentos, Universidade Estadual de Campinas (UNICAMP), Campinas, Brazil, 2004.

[95] G. I. Feovila, "Fungal carotenoids: their biological functions and practical use," Applied Biochemical Bioengineering, vol. 30, pp. 143-153, 1994.

[96] L. J. Borowitzka and M. A. Borowitzka, " $\beta$-carotene production with algae," in Biotechnology of Vitamins, Pigments and Growth Factors, J. E. Vandamme, Ed., pp. 15-26, Elsevier Applied Science, New York, NY, USA, 1989.

[97] L. Dufossé, "Microbial production of food grade pigments," Food Technology and Biotechnology, vol. 44, no. 3, pp. 313-321, 2006.

[98] J. D. Fontana, B. Czeczuga, T. M. B. Bonfim et al., "Bioproduction of carotenoids: the comparative use of raw sugarcane juice and depolymerized bagasse by Phaffia rhodozyma," Bioresource Technology, vol. 58, no. 2, pp. 121-125, 1996.

[99] P. Davoli, V. Mierau, and R. W. S. Weber, "Carotenoids and fatty acids in red yeasts Sporobolomyces roseus and Rhodotorula 
glutinis," Applied Biochemistry and Microbiology, vol. 40, no. 4, pp. 392-397, 2004.

[100] Y.-S. Liu, J.-Y. Wu, and K.-P. Ho, "Characterization of oxygen transfer conditions and their effects on Phaffia rhodozyma growth and carotenoid production in shake-flask cultures," Biochemical Engineering Journal, vol. 27, no. 3, pp. 331-335, 2006.

[101] C. P. Aguilar, M. González, A. S. Cifuentes, and M. Silva, "Growth and accumulation of total carotenoids in two strains of Dunaliella salina Teod. (Chlorophyceae) from the northern and central coast of Perú," Journal of the Chilean Chemical Society, vol. 49, no. 1, pp. 69-74, 2004.

[102] M. R. Fazeli, H. Tofighi, N. Samadi, and H. Jamalifar, "Effects of salinity on $\beta$-carotene production by Dunaliella tertiolecta DCCBC26 isolated from the Urmia salt lake, north of Iran," Bioresource Technology, vol. 97, no. 18, pp. 2453-2456, 2006.

[103] M. Orosa, D. Franqueira, A. Cid, and J. Abalde, "Analysis and enhancement of astaxanthin accumulation in Haematococcus pluvialis," Bioresource Technology, vol. 96, no. 3, pp. 373-378, 2005.

[104] E. Valduga, A. Valério, H. Treichel, A. F. Júnior, and M. L. Di, "Optimization of the production of total carotenoids by Sporidiobolus salmonicolor (CBS 2636) using response surface technique," Food and Bioprocess Technology, vol. 2, no. 4, pp. 415421, 2009.

[105] P. Kaiser, P. Surmann, G. Vallentin, and H. Fuhrmann, "A smallscale method for quantitation of carotenoids in bacteria and yeasts," Journal of Microbiological Methods, vol. 70, no. 1, pp. 142-149, 2007.

[106] N. B. Perdigão, F. C. Vasconcelos, I. H. Cintra, and M. Ogawa, "Extração de carotenóides de carapaças de crustáceos em óleo," Boletim Técnico Científico da CEPENE, vol. 3, no. 1, pp. 234-246, 1995.

[107] Z. Gu, C. Deming, H. Yongbin, C. Zhigang, and G. Feirong, "Optimization of carotenoids extraction from Rhodobacter sphaeroides," LWT_Food Science and Technology, vol. 41, no. 6, pp. 1082-1088, 2008.

[108] H.-M. Chen, S. P. Meyers, and H. S. L. Biede, "Color stability of astaxanthin pigmented rainbow trout under various packaging conditions," Journal of Food Science, vol. 49, no. 5, pp. 1337-1340, 1984.

[109] A. Gildberg and E. Stenberg, "A new process for advanced utilisation of shrimp waste," Process Biochemistry, vol. 36, no. 8-9, pp. 809-812, 2001.

[110] H. D. Holanda, Hidrólise enzimática do resíduo do camarão sete-barbas (Xiphopenaeus kroyeri) e caracterização dos subprodutos [Doctoring Thesis (Food Engineering)], Faculdade de Engenharia de Alimentos, Universidade Estadual de Campinas (UNICAMP), Campinas, Brazil, 2004.

[111] A. Rawson, B. K. Tiwari, M. G. Tuohy, C. P. O’Donnell, and N. Brunton, "Effect of ultrasound and blanching pretreatments on polyacetylene and carotenoid content of hot air and freeze dried carrot discs," Ultrasonics Sonochemistry, vol. 18, no. 5, pp. 11721179, 2011.

[112] M. Markom, M. Hasan, W. R. W. Daud, H. Singh, and J. M. Jahim, "Extraction of hydrolysable tannins from Phyllanthus niruri Linn.: effects of solvents and extraction methods," Separation and Purification Technology, vol. 52, no. 3, pp. 487-496, 2007.

[113] E. Reverchon and I. De Marco, "Supercritical fluid extraction and fractionation of natural matter," The Journal of Supercritical Fluids, vol. 38, no. 2, pp. 146-166, 2006.
[114] L. M. Kopas and J. J. Warthesen, "Carotenoid photostability in raw spinach and carrots during cold storage," Journal of Food Science, vol. 60, no. 4, pp. 773-776, 1995.

[115] F. De Sio, L. Servillo, R. Loiuduce, B. Laratta, and D. A. Castaldo, "A chromatographic procedure for the determination of carotenoids and chlorophylls in vegetable products," Acta Alimentaria, vol. 30, no. 4, pp. 395-405, 2001.

[116] C. M. Babu, R. Chakrabarti, and K. R. S. Sambasivarao, "Enzymatic isolation of carotenoid-protein complex from shrimp head waste and its use as a source of carotenoids," LWT-Food Science and Technology, vol. 41, no. 2, pp. 227-235, 2008.

[117] F. Shahidi and J. Synowiecki, "Isolation and characterization of nutrients and value-added products from snow crab (Chinoecetes opilio) and shrimp (Pandalus borealis) processing discards," Journal of Agricultural and Food Chemistry, vol. 39, no. 8, pp. 1527-1532, 1991.

[118] J. J. Negro and J. Garrido-Fernández, "Astaxanthin is the major carotenoid in tissues of white storks (Ciconia ciconia) feeding on introduced crayfish (Procambarus clarkii)," Comparative Biochemistry and Physiology B: Biochemistry and Molecular Biology, vol. 126, no. 3, pp. 347-352, 2000.

[119] A. Saito and L. W. Regier, "Pigmentation of brook trout (Salvelinus fontinalis) by feeding dried crustacean waste," Journal Fish Research, vol. 28, pp. 509-512, 1971.

[120] N. M. Sachindra and N. S. Mahendrakar, "Process optimization for extraction of carotenoids from shrimp waste with vegetable oils," Bioresource Technology, vol. 96, no. 10, pp. 1195-1200, 2005.

[121] A. K. Taungbodhitham, G. P. Jones, M. L. Wahlqvist, and D. R. Briggs, "Evaluation of extraction method for the analysis of carotenoids in fruits and vegetables," Food Chemistry, vol. 63, no. 4, pp. 577-584, 1998.

[122] M. A. A. Meireles, "Supercritical extraction from solid: process design data (2001-2003)," Current Opinion in Solid State and Materials Science, vol. 7, no. 4-5, pp. 321-330, 2003.

[123] G. Brunner, Gas Extraction: An Introduction to Fundamentals of Supercritical Fluids and the Application to Separation Process, vol. 4, Steinkopff, Darmstadt, Germany, 1994.

[124] J. Martinez, P. T. V. Rosa, C. Menut et al., "Valorization of brazilian vetiver (Vetiveria zizanioides (L.) Nash ex Small) oil," Journal of Agricultural and Food Chemistry, vol. 52, no. 21, pp. 6578-6584, 2004.

[125] P. T. V. Rosa and M. A. A. Meireles, "Supercritical technology in Brazil: system investigated (1994-2003)," Journal of Supercritical Fluids, vol. 34, no. 2, pp. 109-117, 2005.

[126] E. M. Z. Michielin, L. F. V. Bresciani, L. Danielski, R. A. Yunes, and S. R. S. Ferreira, "Composition profile of horsetail (Equisetum giganteum L.) oleoresin: comparing SFE and organic solvents extraction," The Journal of Supercritical Fluids, vol. 33, no. 2, pp. 131-138, 2005.

[127] B. Díaz-Reinoso, A. Moure, H. Domínguez, and J. C. Parajó, "Supercritical $\mathrm{CO}_{2}$ extraction and purification of compounds with antioxidant activity," Journal of Agricultural and Food Chemistry, vol. 54, no. 7, pp. 2441-2469, 2006.

[128] J. M. A. Araújo, Química de Alimentos: Teoria e Prática, UFV, Viçosa, Brazil, 2nd edition, 1999.

[129] J. C. de la Fuente, B. Oyarzún, N. Quezada, and J. M. del Valle, "Solubility of carotenoid pigments (lycopene and astaxanthin) in supercritical carbon dioxide," Fluid Phase Equilibria, vol. 247, no. 1-2, pp. 90-95, 2006.

[130] S. B. Hawthorne and D. J. Miller, "Extraction and recovery of polycyclic aromatic hydrocarbons from environmental solids 
using supercritical fluids," Analytical Chemistry, vol. 59, no. 13, pp. 1705-1708, 1987.

[131] T. Bamberger, J. C. Erickson, C. L. Cooney, and S. K. Kumar, "Measurement and model prediction of solubilities of pure fatty acids, pure triglycerides, and mixtures of triglycerides in supercritical carbon dioxide," Journal of Chemical \& Engineering Data, vol. 33, no. 3, pp. 327-333, 1988. 

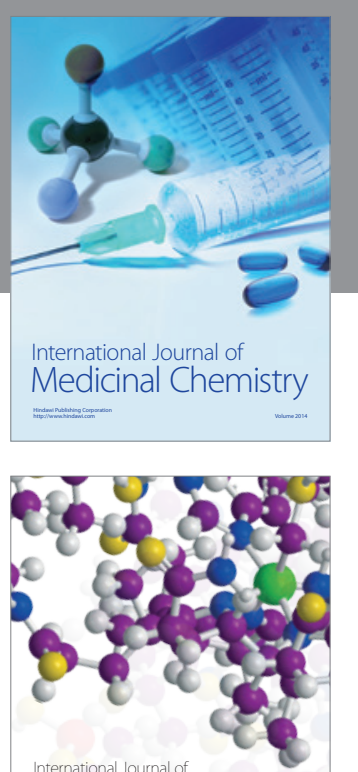

Carbohydrate Chemistry

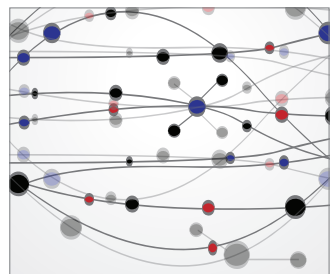

The Scientific World Journal
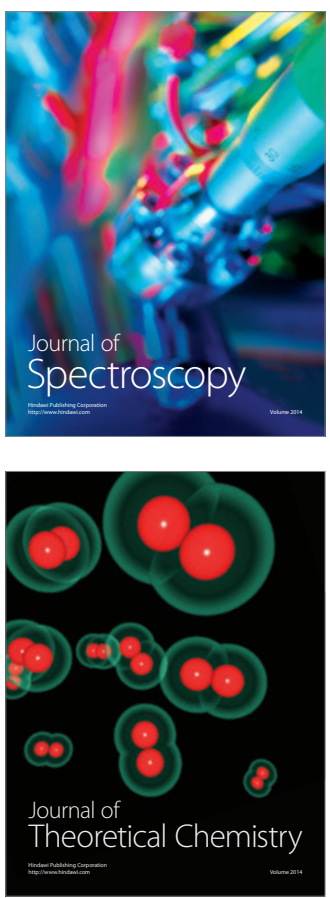
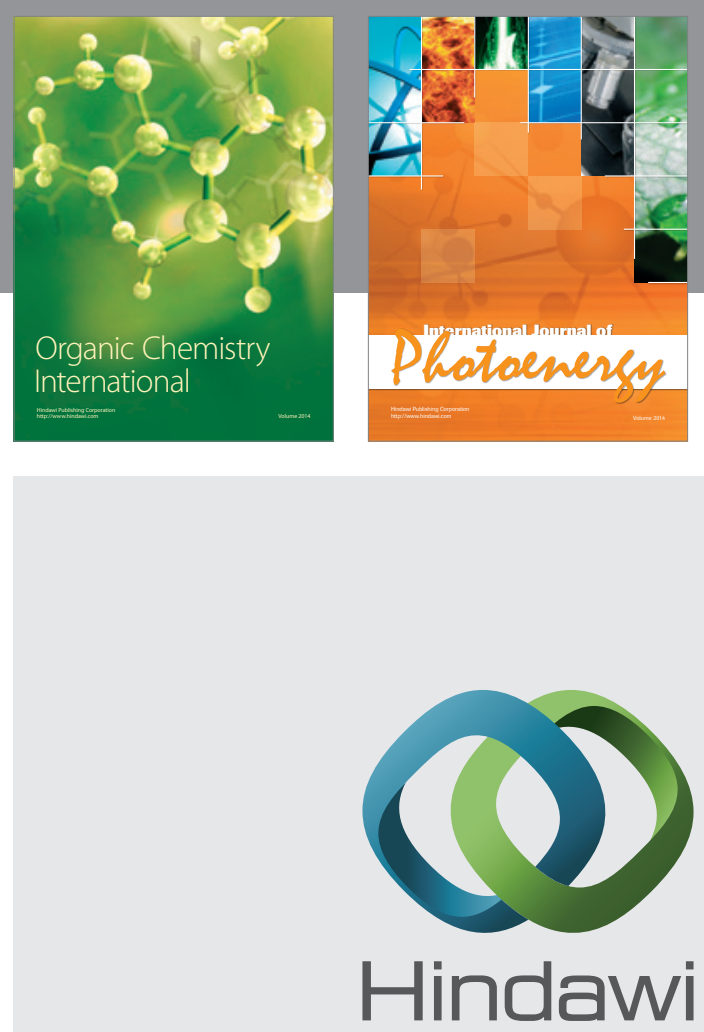

Submit your manuscripts at

http://www.hindawi.com

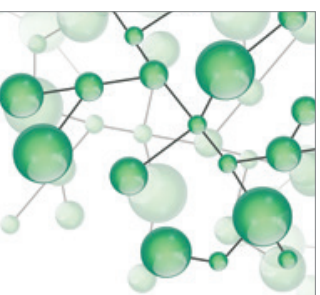

International Journal of

Inorganic Chemistry

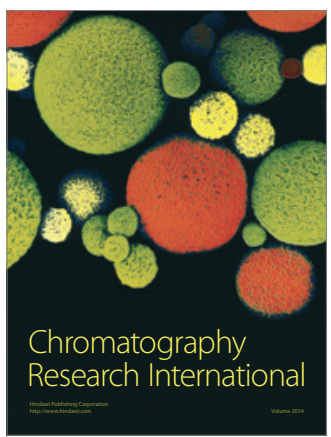

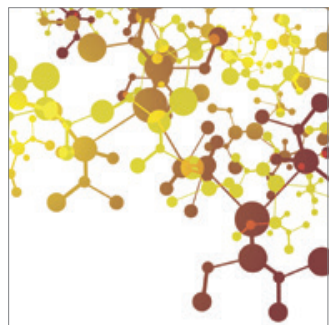

Applied Chemistry
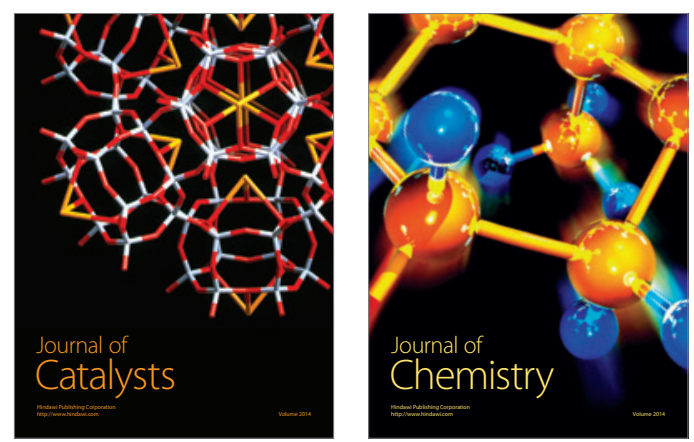
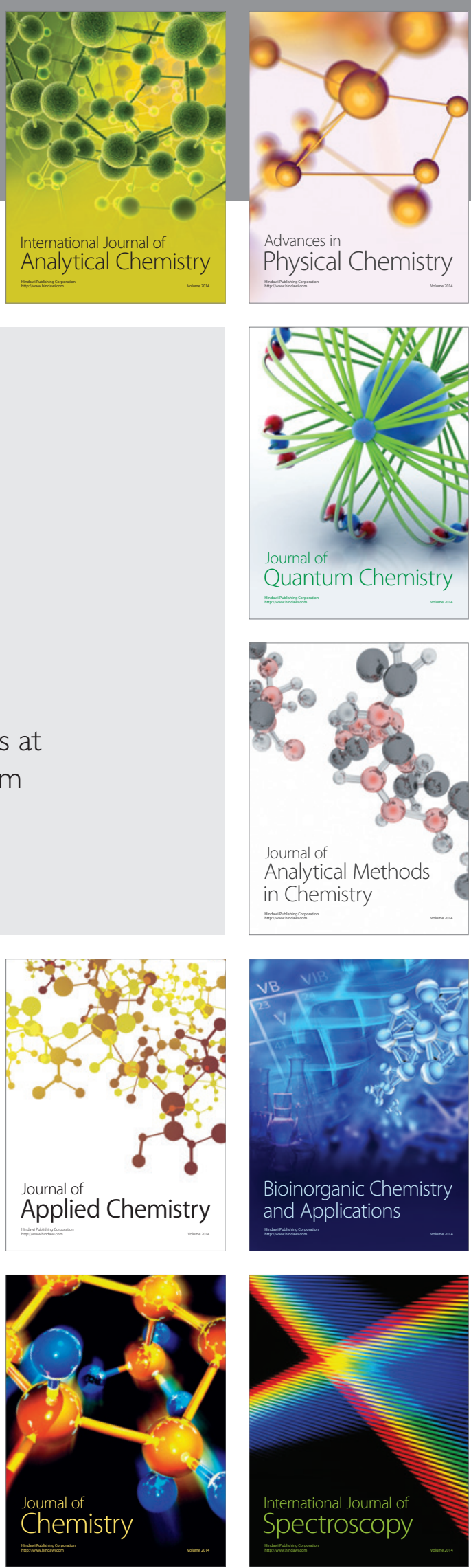